\title{
RECENT JUDICIAL DEVELOPMENTS OF INTEREST TO OIL AND GAS LAWYERS
}

FRANK R. FORAN, Q.C. RANDALL W. BLOCK

PATRICK W. BURGESS ${ }^{*}$

TABLE OF CONTENTS

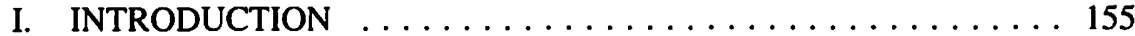

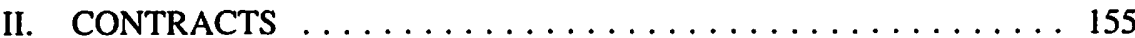

A. TRILOGY RESOURCE CORPORATION

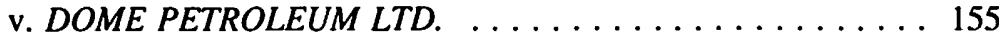

B. LUSCAR LTD. v. PEMBINA RESOURCES LIMITED . . . . . 157

C. MESA OPERATING LTD. a PARTNERSHIP

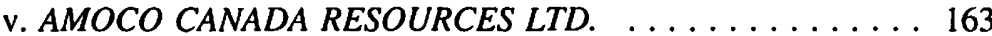

D. UNITED CANSO OIL \& GAS LTD.

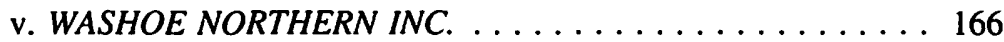

E. ENCHANT RESOURCES LTD.

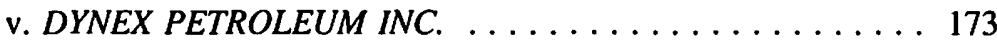

F. KELES PRODUCTION COMPANY LTD. v. HUSKY OIL OPERATIONS LTD. . . . . . . . . . . . . 174

G. PRISM PETROLEUM LTD. et al.

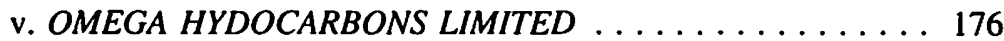

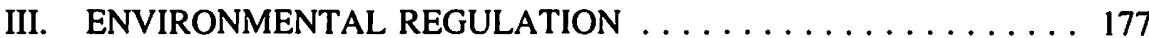

A. FRIENDS OF THE OLDMAN RIVER SOCIETY

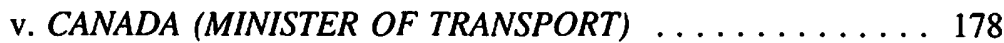

B. SASKATCHEWAN WATER CORPORATION

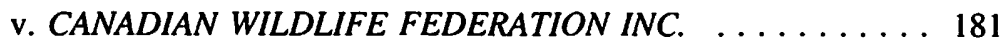

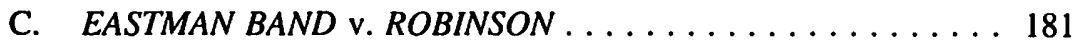

D. QUEBEC (ATTORNEY GENERAL)

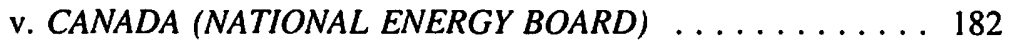

E. SASKATCHEWAN ACTION FOUNDATION FOR THE ENVIRONMENT INC. v. SASKATCHEWAN (MINISTER OF THE ENVIRONMENT AND PUBLIC SAFETY) . . . . . 183

F. R. v. RICHARD BREMNER AND BREMNER ENGINEERING AND CONSTRUCTION LIMITED . . . . . . 185

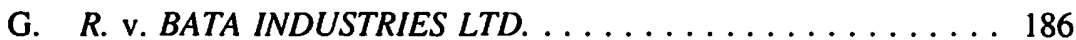

IV. DIRECTOR'S LIABILITY $\ldots \ldots \ldots \ldots \ldots \ldots \ldots \ldots \ldots 186$

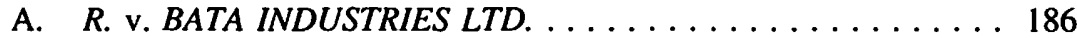

B. AIR CANADA v. $M \& L$ TRAVEL LTD.,

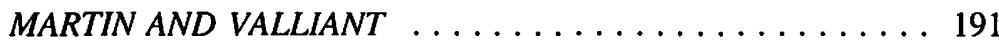

V. CREDITORS' RIGHTS . . . . . . . . . . . . . . . . . . . 194 
A. NATIONAL BANK OF CANADA v. ARGYLL ENERGY CORPORATION, ARGYLL RESOURCES LTD. AND PATCO RESOURCES INC.

B. KARL MUELLER CONST. LTD. v. COMMISSIONER OF NORTHWEST TERRITORIES

C. TRANSGAS LTD. v. MID-PLAINS CONTRACTORS LTD.

D. HAMILTON BROTHERS CORPORATION v.

ROYAL TRUST CORP OF CANADA . . . . . . . . . . . 198

VI. TAX

A. PRECAMBRIAN SHIELD RESOURCES LTD.

v. ALBERTA (PROVINCIAL TREASURER) . . . . . . . . 199

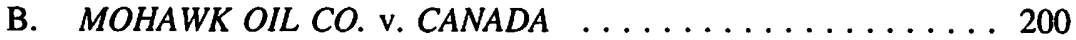

C. TRANSGAS LTD. v. MID-PLAINS

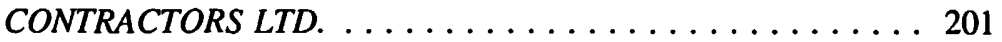

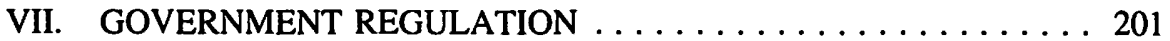

A. RE ANGUS et al. and THE QUEEN et al. . . . . . . . . . 201

B. KENNIBAR RESOURCES LTD. v. SASKATCHEWAN

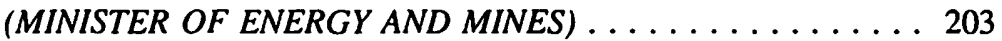

VIII. SURFACE RIGHTS . . . . . . . . . . . . . . . 203

A. GANNON BROS. ENERGY LTD. v. VAN STRATEN . . . . 203

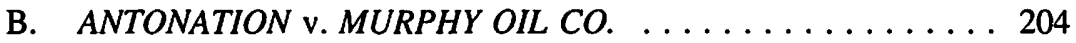

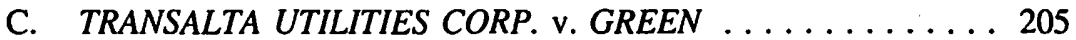

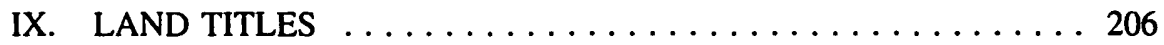

A. CANADA CEMENT LAFARGE LTD. v. MANITOBA . . . . . 206

B. CANADIAN SUPERIOR OIL LTD. v. JACOBSON . . . . . 207

C. CANCO OIL AND GAS LTD. v. SASKATCHEWAN . . . . . 208

D. CANCO OIL AND GAS LTD. v. SASKATCHEWAN . . . . . . 209

E. AMOCO CANADA RESOURCES LTD.

v. POTASH CORPORATION OF SASKATCHEWAN . . . . 210

F. CANADA (DIRECTOR OF SOLDIER SETTLEMENT)

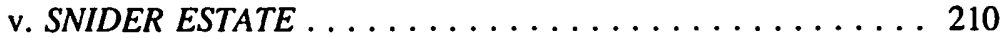

G. ALTA. (MINISTER OF FORESTRY, LANDS \&

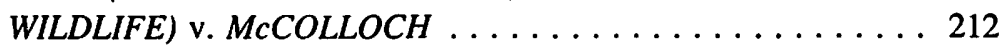

H. ALTA. (MINISTER OF FORESTRY, LANDS \&

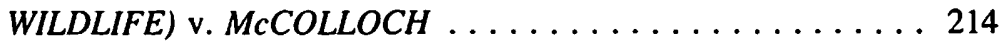

I. LAC LA RONGE INDIAN BAND v. BECKMAN ... . . . 214

J. SHAGANAPPI VILLAGE SHOPPING CENTRE LTD.

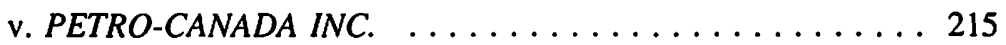

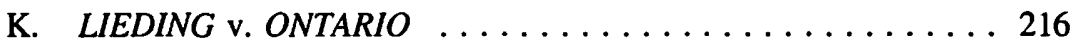

L. DUNCAN v. WEST KOOTENAY POWER

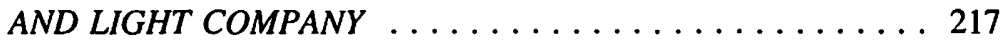

$X$. LEAVE TO APPEAL TO SUPREME COURT

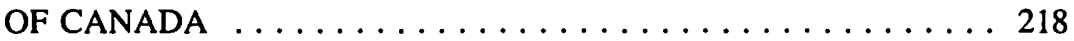

A. AIR CANADA v. $M \& L$ TRAVEL $L T D . \ldots \ldots \ldots \ldots \ldots 218$

B. BAVARIAN LION CO. v. ALBERTA

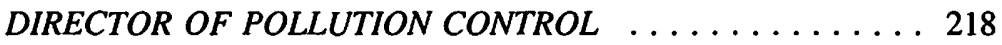




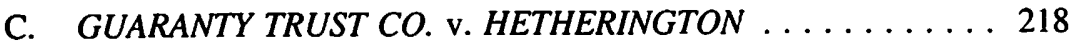

D. MOHAWK OIL CO. v. CANADA .............. 218

E. PANAMERICANA DE BIENES Y SERVICIOS

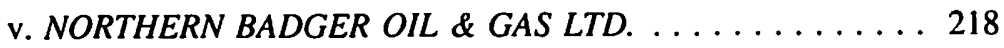

F. R. v. FOOTHILLS PIPE LINES

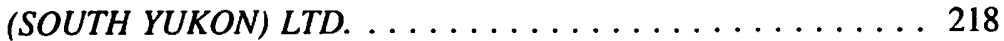

G. FOREST OIL CORP. v. HUSKY OIL

OPERATIONS LTD.

\section{INTRODUCTION}

There has been no shortage of cases of interest to oil and gas lawyers over the last year. Our biggest problem has been to select the most significant judicial decisions for inclusion in this paper. We have attempted to focus on cases which we believe to be of particular interest to lawyers practising general oil and gas law. As has been done in past "Recent Judicial Developments" papers, we have grouped cases under various headings for ease of reference. However, not surprisingly, due to the complex nature of the oil and gas industry, many cases feature a number of issues and could be listed under a number of headings. Finally, we have obviously attempted to catch the essence of the cases. However, a number of the decisions are extremely lengthy and the actual case report should be referred to for a thorough understanding of the case.

\section{CONTRACTS}

\section{A. TRILOGY RESOURCE CORPORATION v. DOME PETROLEUM LTD.'}

The trial decision in Trilogy Resource Corporation v. Dome Petroleum Ltd. was reported in last year's review of cases. The case made its way to the Court of Appeal this year, and it may be reported again next year, as a new trial was ordered.

On July 22, 1977, the appellant, Dome, made an agreement with a partnership known as "ADA" for the acquisition, exploration, and development of mines and minerals. ${ }^{2}$ Dome was appointed the managing operator under the agreement. During the course of acquiring and developing oil and gas properties, a debt arose from ADA to Dome in the amount of almost $\$ 10,000,000$. At least two successful gas wells were drilled, the 11-15 Well and the 7-22 Well. In 1978, an agreement was made regarding the terms of payment and security of the accumulated debt of ADA. Also in 1978, Dome entered a gas purchase contract with TransCanada Pipelines Limited. Gas from the 11-15 Well and 7-22 Well was dedicated to the contract. On October 1, 1979, Dome and ADA entered a further agreement (the "1979 Agreement") regarding the debt owing by ADA which at that time was in the approximate amount of $\$ 9,800,000$. The 1979 Agreement divided the properties in which ADA had an interest into two groups. The first group was encumbered with repayment of the debt. The other group was not encumbered with any

[1992] I W.W.R. 716 (Alta C.A.).

Pursuant to a Court approved arrangement, Dome Petroleum Lid. was reorganized into Amoco

Canada Resources Ltd. 
charge to Dome for the debt (the "Retained Lands"). The 11-15 Well was among the encumbered group, whereas the 7-22 Well was part of the Retained Lands. Therefore, production revenues from the 11-15 Well were available to Dome to repay the indebtedness of ADA whereas production revenue from the 7-22 Well was not.

On December 31, 1980, ADA entered into an agreement assigning its interest in the lands to the predecessor of the respondent Trilogy. On November 11, 1981, Dome prepared and executed a consent to assignment. In 1980, Dome began production from the two wells. Production came disproportionately from the 11-15 Well. Production stopped entirely from the 7-22 Well in 1987. Trilogy sued alleging Dome breached its contractual obligations to produce gas from the Retained Lands as required by the 1979 Agreement and that Dome breached fiduciary duties. In reply, Dome argued that Trilogy had no rights under the 1979 Agreement, that Dome had complied with its contractual obligations and that no fiduciary duties were owed or breached. Medhurst $\mathrm{J}$. at trial held that Trilogy was novated into the 1979 Agreement and that Dome had breached its contractual obligation to produce sufficient gas from the Retained Lands. Dome appealed.

Two claims were dismissed by the Court of Appeal. Trilogy successfully asserted at trial that Dome expressly assured ADA in the 1979 Agreement that it would produce a guaranteed minimum amount of gas from the 7-22 Well. The Court of Appeal rejected this argument and stated: ${ }^{3}$

The argument accepted by the learned trial judge seems to be that this right was somehow converted by the agreement in October 1979 to a right not to production but to a share of ovcrall profits. That is not an interpretation the Agreement can reasonably bear.

Secondly, the Court held there was no merit to the argument of Dome that the interests under the 1979 Agreement were unenforceable except by ADA. The court held that Dome had consented to the transfer from ADA to the predecessor of Trilogy.

A new trial, however, was ordered on the issue of why more gas was not in fact produced from the 7-22 Well. The Court of Appeal held that the trial judge failed to deal with the critical evidence of Dome that no more production could be obtained from the 7-22 Well because of low pressure problems. Moreover, the Court of Appeal held that the trial judge failed to consider the significance of Dome's testimony that it did not go ahead with connecting the 7-22 Well to another pipeline (which would have required the installation of a compressor) because Trilogy would not agree to the expense. As there were credibility issues and conflicting testimony between the Dome and Trilogy witnesses, a new trial was ordered. The Court of Appeal attempted to narrow the issues for trial as follows: ${ }^{4}$

The trial might involve inquiry into this issue: Dome supplied raw data to Trilogy, and before it to ADA, but never its scientific interpretations. Is it as managing operator of a partnership permitted to do that? 
Perhaps a trade custom governs, but, in its absence, the high duty of the manager might oblige it to tell the investor everything it knows. Clarification of that might assist the resolution of this disputc.

This issue, the extent of the "high duty" of a managing operator, permeated many of the important cases during the last year. In Luscar v. Pembina, infra Egbert J. held that the managing operator owed fiduciary duties to its joint operators. In Mesa v. Amoco, infra no fiduciary duties were found, but rather a duty to act in good faith. In Trilogy, the Court of Appeal seems to hint that the managing operator must "tell the investor everything it knows." This appears to have been the position of Egbert J. in Luscar v. Pembina which is discussed below.

\section{B. LUSCAR LTD. v. PEMBINA RESOURCES LIMITED}

An area of mutual interest ("AMI") clause was considered by the court in Luscar v. Pembina. This, in turn, forced the court to consider the existence and scope of fiduciary duties where the parties have agreed to an AMI and wrestle with the thorny issue of limitation periods.

On March 16, 1963, an Operating Agreement was entered into among Zenmac Metal Mines Ltd. (predecessor to Pembina Resources Ltd.), Stanwell Oil \& Gas Limited (predecessor to Luscar Ltd.) and Ranvik Oils Limited (predecessor to Norcen Energy Resources Limited). Zenmac was appointed manager operator of the joint lands pursuant to the provisions of the operating agreement. The operating agreement contained a provision protecting the manager operator from actions save and except arising from "fraud, dishonesty or gross neglect on the part of its officers." The agreement contained an AMI, encompassing township 39, requiring written notice to other parties. Upon receipt of the written notice, a party had 30 days within which to elect to participate in additional interests within the AMI.

Several additional interests were acquired by Pembina within the AMI, some of which were offered to the non-operators and some of which were not. Three separate acquisitions by Pembina within AMI were in issue before Justice Egbert.

On July 20, 1971 Pembina, with Francana Oil and Gas Limited, acquired at a Crown land sale an interest in the east half of section 11 and the west half of section 12-39-3-W5M (the "Crown Lands"). The Crown Lands were located within the AMI and no written notice of these acquisitions was given to Norcen and Luscar pursuant to the terms of the AMI clause. By an agreement dated February 27, 1975, Pembina purchased the oil and gas interests of Cabot Carbon of Canada Ltd. (the "Cabot Lands"). Some of these lands were included within the AMI. It was alleged that no notice of the acquisition, written or verbal, was given by Pembina to Norcen or Luscar. Effective January, 1976, Pembina pooled its interest in the west half of section 12 with other working interest owners in the east half of section 12 for the purpose of creating a gas drilling spacing unit (the "Pooled Lands"). The east half of section 12 was within the AMI. It was alleged that no notice was given of this acquisition. 
In late 1983, a law firm performed a title opinion on Pembina's lands as part of a financing with a bank. Deficiencies relating to the Crown Lands, the Cabot Lands and the Pooled Lands were raised by the law firm. A land manager of Pembina received the title opinion and questioned certain employees of Pembina concerning township 39. There appeared to be no documents indicating that participation in the acquisition of the Crown Lands had been offered to Norcen or Luscar. The land manager then telephoned an employee in the land department of Norcen and asked her "hypothetically" what Norcen would do if it discovered it had breached the provisions of an AMI clause. The Norcen employee replied that Norcen would "own up" to its mistake. Independently, Norcen reviewed a map of the area and came to the conclusion that Pembina had acquired interests in breach of the AMI clause. On December 14, 1983, a senior landman and land manager of Norcen wrote to Pembina advising that Norcen was aware that Pembina had purchased or otherwise acquired lands and drilled wells within the AMI. They requested the necessary information to allow Norcen to elect whether or not to acquire a one-third interest. About that time, Pembina retained counsel who wrote to Norcen on June 19, 1984 and advised that any claim by Norcen was statute barred as the applicable limitation period was six years. The plaintiffs disagreed and brought their action in breach of contract, breach of fiduciary duty, breach of trust and unjust enrichment. ${ }^{6}$

Mr. Justice Egbert held there was no written notice given by Pembina at any time to either Norcen or Luscar of the acquisitions by Pembina of the Crown Lands, the Cabot Lands or the Pooled Lands. The court also held that at no time did Norcen or Luscar waive their rights to be informed of any acquisition by Pembina within the AMI or to participate in the acquisition of the Crown Lands, the Cabot Lands or the Pooled Lands.

Mr. Justice Egbert gave his reasons for judgment under the following headings:

\section{Breach of Contract}

Pembina had breached the provisions of the AMI by failing to give notice in writing of its acquisition of interests within the AMI.

6. An interesting evidentiary aspect of the case was that Mr. Campbell, chief landman of Francana in 1971, attempted to give evidence that in the course of a discussion with Mr. Gordon Christie of Pembina (deceased at time of trial), Mr. Christie advised Mr. Campbell that they had partners in the AMI but the partners were not interested in bidding along with Francana and Pembina. The evidence of Mr. Campbell was obviously hearsay; the issue was whether or not there was an applicable exception to the hearsay rule as to admit Mr. Campbell's evidence for the truth of its contents. Mr. Justice Egbert held that none of the exceptions to the hearsay rule were applicable and, therefore, excluded Mr. Campbell's evidence on the basis that it was double hearsay. 


\section{Nature and Scope of Relationship between the Parties}

Justice Egbert held that Norcen, Luscar and Pembina stood in fundamentally the same relationship to each other as had Ranvik, Stanwell and Zenmac. Norcen and Luscar alleged that, as a result of the terms of the agreement, there was a fiduciary relationship among the parties. Mr. Justice Egbert referred to Frame v. Smith, as adopted by the majority of the Supreme Court of Canada in Lac Minerals Ltd. v. International Corona Resources Ltd., ${ }^{8}$ as establishing the test for the existence of a fiduciary relationship:"

Relationships in which a fiduciary obligation have been imposed seem to possess three general characteristics:

(1) The fiduciary has scope for the exercise of some discretion or power.

(2) The fiduciary can unilaterally exercise that power or discretion so as to affect the beneficiary's legal or practical interests.

(3) The beneficiary is peculiarly vulnerable to or at the mercy of the fiduciary holding the discretion or power.

Egbert J. concluded that this test was satisfied as:

(1) Pembina had scope for the exercise of some discretion or power as it was given exclusive management and control of the exploration and operation of the joint lands (with minor exceptions).

(2) Pembina, in the exercise of this power, could unilaterally affect the interests of Norcen and Luscar.

(3) Norcen and Luscar (and originally Ranvik and Stanwell) were vulnerable to Pembina's unilateral action.

Accordingly, he was of the opinion that the terms of the agreement and the position of Pembina as manager operator created a fiduciary relationship between the parties.

Mr. Justice Egbert went further. He held that the AMI clause in and of itself created a fiduciary relationship. The scope of the fiduciary relationship is set forth in the agreement. He held that the AMI clause: ${ }^{10}$

Supra note 5 at 69 . This is the same test referred to by Shannon J. in Mesa v. Dome, infra. Shannon $\mathrm{J}$. in Mesa held that no fiduciary relationship existed. 
... succinctly spells out other fiduciary obligations and duties. It bluntly and unambiguously states that any party desirous of acquiring or who does acquire an interest of any kind in the lands contained within the AMI shall give notice of such desire or acquisition to the other parties to enable them to decide if they wish to participate in the acquisition.

A breach of this provision, in the opinion of Egbert J., was not only a breach of a contract but a breach of a fiduciary duty. Concurrent causes of action existed. This conclusion was particularly significant in relation to the limitation defence raised by Pembina. By establishing a concurrent cause of action in unjust enrichment, the plaintiff was able to circumvent the contractual limitation period.

Egbert J. also held that Pembina, as operator, was obligated to optimize exploration and exploitation of the lands. Pembina breached its fiduciary obligations when developing a play with respect to sections 11,12 and 14 by not informing Norcen and Luscar but instead involving Francana. Participation in the play was a "corporate opportunity" available to Norcen and Luscar which was worthy of protection by the court. This finding is significant. Pembina's obligations were not to simply comply with the terms of the AMI clause. It was required, because of its fiduciary relationship to the non-operators, to provide all information on the play it was developing to Luscar and Pembina." AMI clauses are common in the industry, and therefore Egbert J.'s conclusion could cause a great deal of concern. What if some or all of the information relating to an operator's decision to acquire interests within the AMI comes from sources outside the joint lands? Is the operator required to share this information with its joint operators?

In summary, Mr. Justice Egbert held that the relationship between Norcen, Luscar and Pembina was both contractual and fiduciary in nature and Pembina owed fiduciary duties arising out of its position as manager operator under the terms of the agreement and from the specific terms of the AMI clause. Both the contractual and fiduciary duties were breached by Pembina.

Mr. Justice Egbert also held that it was the intention of the parties as disclosed in the AMI clause that if any interest was acquired within the AMI, that interest would be held in trust for the other parties until such time as written notice was given and the $\mathbf{3 0}$ day period expired within which to elect to acquire a portion of the interest. The AMI clause created an express trust, or at the very least an implied trust, as there was certainty of words, certainty of subject matter and certainty of the persons. That being the case, the Crown Lands, Cabot Lands and the Pooled Lands were and continued to be held in trust by Pembina on behalf of Norcen and Luscar. 


\section{Unjust Enrichment}

Mr. Justice Egbert held that a plaintiff is entitled to select a cause, or causes, of action that provides the most appropriate remedy. As such, Luscar and Norcen were entitled to pursue their claim in unjust enrichment. The fact of the existence of a contract between the parties in this case did not bar an action in unjust enrichment. The Court held that the existence of a contract is a bar to a claim in unjust enrichment only where the parties have fully performed their obligations under the contract. The Court held that the well known requirements of unjust enrichment set forth in Pettkus v. Becker ${ }^{12}$ had been met in that:

(1) Pembina had been enriched;

(2) Norcen and Luscar had been deprived of the net revenue from the additional interests acquired; and

(3) there was no juristic reason for the enrichment.

\section{Limitation of Actions Act $^{13}$}

The limitation period for a claim in breach of contract is six years. There had been some judicial dispute about whether the six years runs from breach or from when the breach was discovered or could have reasonably been discovered. The Alberta Court of Appeal in Fidelity Trust Co. v. 98956 Investments Ltd. $^{14}$ confirmed that the cause of action for breach of contract arises upon breach regardless of whether or not the breach was discovered. Mr. Justice Egbert disagreed with the position of the Court of Appeal, but nevertheless considered himself bound by it. He states: ${ }^{15}$

\footnotetext{
With the greatest respect, I am of the opinion that is not what the Supreme Court said and that a cause of action, in either contract or tort, or, for that matter, any other cause, does not arise and the limitation period does not commence to run until the injured party is aware of his rights or, through reasonable diligence, should be deemed to be aware of them. However, I am bound by the Alberta Court of Appeal and must, therefore, reluctantly hold that the discoverability test set down in Central \& Eastern Trust ${ }^{16}$ and Kamloops ${ }^{17}$ does not apply in Alberta to actions for breach of contract.
}

As a result, the claim of Norcen and Luscar for breach of contract was statute barred.

The plaintiffs had, however, established a concurrent cause of action in unjust enrichment. Mr. Justice Egbert held that the applicable period for a claim in unjust enrichment is six years from the discovery of the cause of action. He further held that Norcen and Luscar did not discover or could not have reasonably discovered the cause

[1980] 2 S.C.R. 834, 19 R.F.L. (3d) 165, 8 E.T.R. 143, 117 D.L.R. (3d) 257, 34 N.R. 384 (S.C.C.). R.S.A. 1980, c. L-15. (1988), 61 Alta L.R. (2d) 193, [1988] 6 W.W.R. 427, 89 A.R.151, 47 C.C.L.T. 80 (Alta C.A.). 
of action until September or October of 1983 (the date of the title opinion), and hence the claim in unjust enrichment was not statute barred. ${ }^{18}$

\section{Remedies}

Although the contract had been breached, the contractual claim was statute barred. The plaintiffs, however, successfully established causes of action in unjust enrichment, breach of fiduciary duty, and breach of trust.

The court held that the appropriate remedy was a declaration of a constructive trust over the Crown Lands, the Cabot Lands, and the Pooled Lands. The constructive trust applied to a $2 / 3$ interest in the properties; $1 / 3$ being the property of each of Norcen and Luscar. In relation to the Crown Lands and the Pooled Lands, as Pembina was only a 50\% owner with Francana holding the balance, the entire interest held by Pembina was declared to be subject to a constructive trust in favour of Norcen and Luscar. The court also directed that Norcen and Luscar advise Pembina in writing within 60 days from the date of judgment whether or not they wished to participate in the acquisition of the interest in the Crown Lands, the Pooled Lands and the Cabot Lands.

In addition, Norcen and Luscar were each granted judgment for $1 / 3$ of the revenues received by Pembina from the Crown Lands and the Pooled Lands since 1971.

The judgment of Justice Egbert is significant for a number of reasons. The court considered the interface of contract and unjust enrichment and concluded that a concurrent action in unjust enrichment will lie unless there has been full performance under the contract. Does this mean that whenever there is breach, a concurrent action in unjust enrichment can be advanced? Justice Hutchinson in United Canso Oil \& Gas Ltd. v. Washoe Northern Inc., infra in distinction to the reasoning of Justice Egbert, held that although the elements of unjust enrichment had been made out, the plaintiff's claim was solely in contract. In the result, the contractual limitation period (six years from breach) was held to apply in United Canso whereas a different limitation period (six years from discoverability) applied in Luscar. In addition, Egbert J. found a fiduciary relationship which required Pembina to disclose all information in its possession relating to a play involving lands within the AMI. The obligations of Pembina were not limited to simply giving the notice set forth in the AMI clause.

18. Limitation of Actions Act, R.S.A. 1980, c. L-15, s 4(1)(e). Alternatively, the Court held the applicable limitation period was $s .4(1)(\mathrm{g})$ which provides a 6 year limitation for "any other action not specifically provided for in the Act." 


\section{MESA OPERATING LTD. a PARTNERSHIP v. AMOCO CANADA RESOURCES LTD. ${ }^{19}$}

Accounting issues were at the forefront of a number of cases in $1991 .^{20}$ The proper calculation of an overriding royalty was before the Alberta Court of Queen's Bench in Mesa Operating Ltd. v. Amoco Canada Resources Ltd. By an agreement dated July 1, 1979 (together with supplemental and amending agreements) Mesa agreed to sell all of its Canadian oil and gas properties to Dome Petroleum Ltd. Mesa, however, reserved an overriding royalty of $12.5 \%$ of the gross proceeds realized upon the sale of all petroleum substances. Although a number of disputes regarding the calculation of the overriding royalty were settled by the parties, three major disputes remained outstanding:

(1) One of the properties acquired by Dome from Mesa was the south half of section 4-35-6-W5M near Caroline, Alberta. Dome owned the north half of the section and, upon drilling a successful gas well on the south half (the "3-4 Well"), pooled it with the north half to form a 640 acre spacing unit. From June 1981 to April 1984, the overriding royalty was calculated on $100 \%$ of production from the 3-4 Well. However, in 1984, Dome unilaterally allocated $1 / 2$ of the production to the north half of section 4 . Mesa argued that the pooling should have been done on a reserves as opposed to an areal basis.

(2) Dome at times elected not to participate under the non-consent provisions of the relevant operating agreements. Mesa claimed that it was entitled to payment of its overriding royalty during the periods where Dome was in a penalty position.

(3) Dome covenanted to give a surrender notice to Mesa of Dome's "desire to surrender... all or any part of its rights or interests in the non-producing properties." A portion of a crown lease was surrendered by Dome. Mesa argued that it was entitled to notice of the surrender and, as it had not received notice and as Dome and related companies had reacquired interests in the surrendered lands, the royalty was payable on the gross proceeds of all petroleum substances produced from wells drilled on those lands.

Mesa was successful in its argument that the 3-4 Well should have been pooled on a reserves as opposed to an areal basis. It argued that Dome breached fiduciary duties or at minimum, its good faith duties by allocating production on an areal rather than a reserves basis. The plaintiff relied, in part, on the Alberta Court of Appeal decision in Bank of Nova Scotia v. Societe General (Canada) ("Sorrel"). ${ }^{21}$ In reaching his decision, Mr. Justice Shannon reviewed the decision of the Supreme Court of Canada in 
International Corona Resources Ltd. v. Lac Minerals Ltd. ("Lac Minerals") 22 and specifically the three part test as to the existence of a fiduciary duty. ${ }^{23}$

The court held that no fiduciary relationship existed between the parties as Mesa could not establish the necessary element of dependency. Shannon J. applied the reasoning of Sopinka J. in Lac Minerals that it is rare that a fiduciary relationship will arise in an arm's length commercial transaction where the parties have an adequate opportunity to prescribe their mutual obligations by contract. Shannon J. held that Sorrel did not assist Mesa for two reasons. First, the court held that the terms of the operating agreement in Sorrel (the 1981 CAPL) could "reasonably support the finding of an implied intention to create a relationship of a fiduciary nature" whereas the agreement between Mesa and Dome could not. Second, the court considered it important that the decision in Sorrel was decided more than a year prior to Lac Minerals. The court held that the test for the existence of a fiduciary relationship was definitively set forth in Lac Minerals. Shannon J. considered that Sorrel was based on trust concepts.

Although Mesa was unsuccessful in establishing a breach of fiduciary duty, it successfully argued that Dome breached an implied obligation of good faith owed to Mesa. Shannon J. stated: ${ }^{24}$

The Canadian test is laid out by the Nova Scotia Supreme Court in Gateway Realty Ltd. v. Arton Holdings Lid....

There the Cour enunciated the principle that there was an obligation on parties to a contract to act in good faith and that duty limits the exercise of discretion conferred on parties by an agreement. In that case it was held that the common law duty to perform in good faith is breached when a party acts in bad faith, that is when a party acts in a manner that substantially nullifies the contractual objectives or causes significant harm to the other, contrary to the original purposes or expectations of the parties.

The court was satisfied on the evidence that the producing reservoir was under the south half of section 4 . When Dome began to allocate one-half of the production to the north half of section 4, the court held that it did so even though it knew or must have suspected that the reservoir was located entirely or substantially under the south half of the section. Although areal pooling was the most common method of pooling, the Court held that Dome knew that other allocations were possible and that provincial legislation provided for recourse to another basis if the areal system was inequitable. The court held as follows: ${ }^{25}$

I find that the knowledge that they possessed at the time of pooling as to the most likely reservoir dimensions and geographical markers should have alerted them to their good faith obligation to consult with Mesa. Only then would Mesa have had a reasonable opportunity to reach an equitable agreement with Dome, or alternatively, urge that an application be made to the ERCB to resolve the matter.

22. $\quad$ Supra note 8.
$23 . \quad$ Ibid.
24. $\quad$ Supra note 19 at 75.
25. $\quad$ lbid. at 81.


The failure to proceed in that manner constituted a breach of the implied term of the contract obliging

Dome to act in good faith.

Thus, although failing to establish a breach of fiduciary duty as there was no fiduciary relationship between the parties, Mesa was successful in establishing a breach of the implied term of the contract requiring Dome to act in good faith.

Mesa also contended that the Mesa royalty was payable on the gross proceeds of all petroleum substances produced from the non-consent wells during the penalty period. The court dismissed this argument on a literal reading of the royalty provision. The agreement provided that the royalty was calculated on "gross proceeds." Gross proceeds were defined as "the proceeds received by the purchaser at the point of sale of the petroleum substances." The election by Dome not to participate in wells resulted in Dome not receiving any "production" and hence no "proceeds from petroleum substances produced" that would attract the calculation of the Mesa royalty.

Mesa contended that it was entitled to notice of the expiry of a crown lease. The agreement required that a surrender notice be given "of purchaser's desire to surrender, allow to expire (except where a continuance is not possible), abandon or release all or any part of its rights or interests in the non-producing properties." Dome argued that it did not "desire" to allow to expire a portion of the crown lease but rather portions of that lease were not permitted to continue as a result of decisions by governmental authorities. Dome was successful in its argument. The court relied on the following statement from a U.S. decision, Lillibridge v. Mesa Petroleum Co.: ${ }^{26}$

The Campbell Court held that an overriding royalty created by an oil and gas lease falls with the lease upon bona fide forfeiture or surrender of the lease; but if "forfeiture or surrender is obtained by fraud or collusion between the landowner and the lessee for the purpose of avoiding or cutting out the overriding royalty," then the holder of the royalty is entitled to relief against such forfeiture.

The court held that there was no fraud or collusion in this case and, therefore, the surrender of the lease by Dome was not actionable. In any event, the court held that any right to recover against Dome was statute barred since more than six years had passed since the cause of action arose. ${ }^{27}$

The case is significant in that Mesa was successful in imposing an express obligation upon an operator to act in good faith. This duty of good faith required the operator to consider reserves as opposed to areal pooling. There has been considerable discussion in recent years as to whether Canadian contract law specifically includes a duty to act in

27. In this regard the Court applied s. 4(I)(c) of the Limitation of Actions Act, R.S.A. 1980, c. L-15, which provides for a six year limitation period for breach of contract. As discussed extensively in Luscar v. Pembina, the Alberta Court of Appeal in Fidelity Trust v. Weiler has held that the six year period runs from breach and not discovery of the breach. Egbert J. in Luscar v. Pembina overcame the limitation defence by allowing the plaintiffs to succeed in an alternative cause of action, unjust enrichment. 
good faith. Shannon J. confirms the good faith requirement in the oil and gas context. In distinction to Luscar v. Pembina, supra Mesa was unsuccessful in establishing a fiduciary relationship between the parties. This result is consistent with the reasoning of Sopinka J. in Lac Minerals that, in a commercial transaction, the court should be hesitant to find a fiduciary relationship as the parties can prescribe their rights and obligations by contract. The three part test established in Frame v. Smith and adopted by the Supreme Court of Canada in Lac Minerals has emerged as the test that must be established before a fiduciary relationship will be found. Finally, Shannon J., as did Hutchinson J. in United Canso Oil and Gas Ltd. v. Washoe Northern, Inc., treated the matter as one of breach of contract. Mr. Justice Egbert, however, in Luscar v. Pembina allowed concurrent actions in unjust enrichment and breach of fiduciary duty thereby avoiding the contractual limitation period. The interplay of unjust enrichment and contract is an issue that may be clarified when the Alberta Court of Appeal hears any or all of the above cases.

\section{UNITED CANSO OIL \& GAS LTD. v. WASHOE NORTHERN INC. ${ }^{28}$}

In the case of United Canso Oil \& Gas Ltd. v. Washoe Northern Inc., the court was called upon to rule on the proper method of calculating debits and credits to three separate carried accounts. ${ }^{29}$ The following parties were involved in the case:

United Canso Oil \& Gas Ltd.: The plaintiff (in receivership at time of trial) successor to Columbian Northland Exploration Ltd. ("CNEL") as the holder of three separate carried interests.

Husky Oil Ltd., and Husky Oil Operations Ltd.:

Asamera Inc:

Lasmer Resources Ltd.:

Finley, Washoe:
Contract operators of the carried accounts from 1969 through 1982. Husky Exploration Inc., another Husky company, held the working interest in the lands subject to the carried accounts. The Husky companies sold their working interest and transferred operatorship to Asamera Inc. effective June 1, 1982.

Successor to Husky's working interest and operatorship.

Successor to Asamera's working interest and operatorship.

Working interest owners throughout. evidence and of the evidence of the draftsman on some of the agreements was reported at (1991), 78 Alta L.R. (2d) 79 (Alta Q.B.).

29. For the purposes of this summary, we have referred to three carried interest accounts. Under the Nordan-O'Connor account, CNEL received an immediate working interest burdened by two production payments. Therefore, CNEL only had a true carried interest under two of the agreements. For the purposes of this summary, the distinction is not material. 
Esso Resources Canada Ltd.:

Original farmor under 1967 Farmout Agreement. Bought the Nordan O'Connor interest in the lands in 1978, and United Canso's interest in the carried accounts from Peat Marwick Thorne Inc. (Receiver and Manager of United Canso) in the fall of 1988.

Under a Farmout Agreement dated April 11, 1967 with Imperial Oil Enterprises Ltd., CNEL acquired the right to earn a 50\% interest in certain Alberta lands, leases and reservations more particularly described in the agreement (the "Quirk Creek Lands"). In May of 1967, three separate Texas partnerships were formed:

\section{$\underline{\text { Partnership }}$}

1. Columbian Finley

Exploration Co.

2. Columbian Northland Exploration Co.

3. Husky Columbian Exploration Co.

\section{$\underline{\text { Partners }}$}

Finley, Washoe and CNEL

Nordan, O'Connor and CNEL

Husky and CNEL

Three separate articles of partnership governed the three partnerships. The articles of partnership provided that CNEL would manage the partnerships, the other partners would provide all the funds, and CNEL would have a carried interest in each partnership that would convert to a working interest once the carrying parties were reimbursed from production. The interest under the Farmout Agreement dated April 11, 1967, was earned and a considerable amount of joint account exploration occurred.

In 1968, a gas purchase contract was entered into with TransCanada Pipelines Limited ("TCPL") which dedicated gas from the Quirk Creek Lands to TCPL and which contained a "take or pay" provision. Prepayments were received by the managing operators and distributed to the parties other than CNEL without crediting the carried accounts. A gas plant was also built to process gas from the Quirk Creek Lands in the early 1970s.

The three partnerships were terminated in 1969. The termination was accomplished through three separate termination agreements dated June 30, 1969. The partnership property under each of the three Texas partnerships (Columbian Finley Exploration Co., Columbian Northland Exploration Co., and Husky Columbian Exploration Co.) was conveyed to the individual partners through three separate conveyance agreements also dated June 30, 1969. The funding partners had yet to be repaid. Hence, CNEL's interest remained "carried" after the termination of the partnerships.

Under each agreement, there were two critical payout dates. Under the Husky and Finley conveyance agreements, CNEL was to have a carried interest until first payout. Once first payout was achieved, CNEL's working interest was to be burdened by a 
production payment that also had to be repaid before CNEL received the full proceeds accruing to its working interest. The Husky and Finley conveyance agreements (substantially identical in terms), set forth the equation for the tabulation of debits and credits to achieve "first payout" and repayment of the production payment or "second payout." The Nordan O'Connor conveyance agreement, in distinction to the Husky and Finley conveyances, provided that CNEL received an immediate working interest; however, that interest was burdened by two production payments. Again, the specific debits and credits were set forth in the Nordan $O^{\prime}$ Connor conveyance agreement. In all three conveyance agreements there was an opening balance representing CNEL's unpaid contributions for the acquisition and development of the Quirk Creek Lands incurred from 1967 through 1969. United Canso alleged that the debits and credits pursuant to the three conveyance agreements were improperly calculated first by Husky and subsequently Asamera and Lasmer with the result that CNEL had a working interest in the Quirk Creek Lands and was entitled to production revenue.

Particularly troublesome in the calculation of the carried accounts was the debit for Canadian income taxes in the first payout. The Husky conveyance provided as follows:

(v) Annual debit entries equal to twenty-five percent (25\%) of the aggregate amount of the Canadian income taxes that would have been incurred by Husky Ex during the applicable periods commencing with the effective date and ending when Payout occurs, assuming that Husky Ex were a Canadian corporation, the only assets of which were the Properties and which had no expenses except those related to the Properties, provided that no debit entries shall be made under this item unless Husky Ex is required to include in its income, for Canadian income tax purpose, a portion of the income referable to Columbian's carried twenty-five percent (25\%) interest in the Properties.

The Finley conveyance contained the same provision, except for the substitution of Finley Parties for Husky Ex. The Nordan-O'Connor conveyance provided:

(iii) An amount equal to the aggregate Canadian income taxes that would have been payable by a Canadian corporation during the applicable periods prior to the final satisfaction of the First Production Payment, assuming that such Canadian corporation owned Twenty Five Percent $(25 \%)$ of the Properties as the only asset of such corporation and had no expenses except those related to the Properties.

Against the various debits in the Husky and Finley conveyances were to be applied:

(vii) Credit entries equal to twenty-five percent (25\%) of the gross proceeds of production hereafter received until Payout occurs after deducting all royalties, overriding royalties and other interests of third parties.

In regard to the Nordan O'Connor conveyance, "net proceeds ... accruing from production" were to be applied against the production payments.

Under a Joint Operating Agreement dated December 15, 1969 (the "Operating Agreement"), Husky initially undertook the obligation of tabulating the various debits and credits to the three carried accounts, and distributing production revenue to the working interest owners. Although there were three separate conveyance agreements, the 
accounting for the carried accounts was performed under one operating agreement. Husky performed this task from 1969 through 1982. Payout statements were sent to the other parties (including CNEL) on a regular (usually monthly) basis. These statements charted the progress of the three accounts towards "first payout." The Operating Agreement provided in clause 6(a) that "Joint-Operator's right of action against Managing-Operator is strictly limited to action for loss, damage, or costs caused by the gross negligence or wilful misconduct of Managing Operator in the performance of, or in the failure to perform, Managing-Operator's obligations under this Agreement."

In 1980, Husky performed the income tax calculation for the tax debit under the conveyance agreements and added this to the payout balance under each conveyance agreement. This had the effect of extending first payout under the conveyance agreements.

From 1969 through 1982 (at which time Husky sold its interest in Quirk Creek along with the obligations of managing operator to Asamera), no material dispute was taken with the way that Husky calculated the carried accounts. On the other hand, no party had conducted a detailed audit of the carried accounts. The relevant agreements did not contain a provision allowing for audits of the carried accounts. Husky was aware in the summer of 1982 that United Canso wished to audit the carried accounts. However, the first written request to audit was in September of 1982 subsequent to Husky's sale of its working interest and transfer of operatorship to Asamera. A contract auditor was retained by United Canso to audit the carried accounts from inception. This audit alleged a great number of deficiencies in the accounting; however, the great majority of these were settled or not pursued. From 1982 through 1985, there were various attempts to resolve the proper calculation of the accounts; these were not successful. In 1985, the parties to the litigation created an "audit committee" to attempt to reach some consensus on the audit exceptions, but this attempt to settle the proper debits and credits to the carried accounts failed. In 1987, litigation was commenced.

The plaintiff brought its action in breach of contract, breach of trust, breach of fiduciary duty and unjust enrichment. The plaintiff argued that at least the following items must be included in the proper calculation of the debits and credits to the carried accounts:

a. take or pay pre-payments received from TCPL as a credit to the carried accounts;

b. Alberta Royalty Tax Credits ("ARTC") as a credit to the income taxes payable;

c. interest charged on the unrecovered balances of the carried interest accounts was an expense in the income tax calculations;

d. the opening balance in the conveyance agreements must be treated as tax pools in calculating the taxes payable;

e. Petroleum and Gas Revenue Tax ("PGRT") is not properly included as a debit to the carried accounts; if it is included, PGRT credits must also be included; and 
f. capital cost allowance for the gas plant was an item properly included in the tax calculation for the notional corporation. Husky, in performing the income tax calculation, had included capital cost allowance for the gas plant.

In response, the defendants asserted the calculation of the carried accounts was performed correctly, and if not, the plaintiff's claims were statute barred as the contract limitation period (6 years from breach) applied. In addition, the managing operators asserted they were protected by clause 6 of the Operating Agreement which limited a joint operator's right of action to "gross negligence or wilful misconduct." Expert accounting and tax evidence was adduced by all parties as well as various other witnesses.

The court held:

\section{Accounting Issues}

a. Take or Pay Pre-payments Received from TCPL:

The plaintiff argued that its portion of the prepayments must be either credited to the carried accounts or paid in cash. The defendants argued, relying on U.S. authority, that prepayments are not "proceeds of production" or "proceeds . . . accruing from production" but rather are akin to a loan.

Hutchinson $\mathrm{J}$. held that the gas purchase contract was an asset of the partnerships which was conveyed to the partners under the 1969 conveyance agreements and that prepayments should have been credited to the carried accounts. Hutchinson J. held:

Columbian was entitled to receive a credit equal to $25 \%$ of the cash prepayments as they were made to and distributed by each Managing Operator in turn as agent for the Joint Operators. The fact that such payments represented cash advances for gas not yet delivered only means that Columbian's $25 \%$ interest in such gas was dedicated for future delivery to TCPL.

\section{b. ARTC:}

The court held that ARTC should be included in the carried accounts, not as a credit against income taxes, but rather as a reduction of royalties.

c. Interest charged on the unrecovered balances in the carried interest accounts was an expense in the income tax calculation:

Interest was held to be an expense in the tax calculation under the Nordan $O^{\prime}$ Connor conveyance but not under the Husky and Finley conveyances. The court did hold, however, that to the extent that Husky or Finley borrowed money to finance the construction of CNEL's portion of the gas plant, this interest expense would be deductible in the notional income tax calculation. The court held that the individual tax characteristics of the Husky and Finley parties would impact on the tax calculation for those carried accounts. 
d. The opening balance in the conveyance agreements must be treated as tax pools in calculating the tax debit:

The court held that the opening balances should not be treated as tax pools, as the tax attributes had already been taken by the carrying parties and therefore were no longer available.

e. PGRT and PGRT Credits:

The court held that PGRT was a debit to the carried accounts. PGRT credits, however, were available on revenue earned after May 31, 1982 (within the Asamera and Lasmer term as managing operators). Hutchinson $J$. held that, subject to further arguments concerning the application of the association rules, the full amount of the PGRT credits should be deducted from the amount of the debit for PGRT.

\section{Defences}

After deciding the accounting issues, Hutchinson J. addressed other defences raised in the action. Turning to the standard required of the managing operators, while the debits and credits for the accounting are set forth in the conveyance agreements, the duty to perform the accounting arose under the Joint Operating Agreement dated December 15, 1969. Clause 6(a) of this agreement provides as follows:

\section{Liability}

Joint-Operator's right of action against Managing-Operator is strictly limited to action, for loss, damage or costs caused by the gross negligence or wilful misconduct of Managing-Operator in the performance of, or in the failure to perform, Managing-Operator's obligations under this Agreement.

The court held that the clause applied and it was necessary for the plaintiff to establish gross negligence. Husky was not guilty of gross negligence except for failing to credit take or pay pre-payments to the carried accounts. Conversely, the court held that Asamera and Lasmer (as successor managing operators to Husky) were grossly negligent and not protected by the above clause.

On the limitation defence, the court held that the plaintiff's claim was in breach of contract both against the successive managing operators and the non-operators. Hutchinson J. applied Fidelity Trust v. 98956 Investments Ltd. and Weiler and Ruzicka v. Costigan and held that the applicable limitation period was 6 years calculated from breach. Hutchinson J. states: ${ }^{30}$

The fact remains that the plaintiff's cause of action as the successor to the Columbian interest in the Carried Interest accounts and Production Payment accounts against the Managing Operators is one in contract. Nothing can demonstrate this more clearly than the fact that the plaintiff requested the Court 
to determine how the accounting should be done correctly, which I have endeavoured to do. In order to reach my conclusions regarding the proper method of accounting, I have had to consult the wording of the Foundation Agreements, that is to say, I have had to interpret the contracts which governed the affairs of the parties to the agreements. Their respective rights and obligations arose from the contracts entered into between them.

Similarly, Hutchinson J. held that the plaintiff's claim to recover monies from the non-operators was also in contract: ${ }^{31}$

Insofar as the plaintiffs action against the Joint Operators is concerned, that action lies in contract rather than in restitution based on unjust enrichment.

A concurrent cause of action in unjust enrichment was advanced by the plaintiff, in part, to avoid the contractual limitation period. Hutchinson J. held that although the plaintiff had established the necessary elements of unjust enrichment, the contractual limitation period still applied: ${ }^{32}$

In my opinion the valid and subsisting agreement between the parties is not a juristic reason for refusing the plaintiff's claim in unjust enrichment. Characterizing the plaintiff's claim this way, however, does not avoid the limitations defence which has been advanced in this case and on which I have previously ruled.

In the result, the carried accounts were to be recalculated from inception; however, the plaintiff's right of recovery was limited to amounts due and owing (if any) subsequent to February 6, 1981 (6 years prior to the issuance of the statement of claim).

The court held that the managing operators (Husky - Asamera - Lasmer) were primarily responsible to the plaintiff during the periods within which they were managing operators. However, they have a right of indemnity from those parties to which they distributed monies. Husky, as managing operator, was only liable for take or pay pre-payments, as it was protected by the "gross negligence" clause in the Operating Agreement.

In this case, Hutchinson $\mathrm{J}$. was called upon to decide complex accounting and interpretation issues governing three separate carried accounts. Many of his findings, especially on the accounting issues, are specific to the particular agreements before him. Hutchinson J.'s conclusions on the limitation defence, however, are noteworthy and should be contrasted with that of Egbert J. in Luscar, supra. Hutchinson J. ruled that, although the requisite elements of unjust enrichment had been made out and the contract had been breached, the contractual limitation period applied. Conversely, Egbert J. ruled that a concurrent cause of action in unjust enrichment could be pursued by the plaintiff and applied a 6 year limitation period from discovery thereby avoiding the limitation defence. 
The court also considered in depth the nature of ARTC and Hutchinson J. held that it is a reduction of Crown royalties payable as opposed to an income tax credit. It is also noteworthy that Hutchinson J. held that prepayments received from TCPL were required to be credited, on the facts of this case, to the carried accounts to reduce the outstanding balance, notwithstanding the "carried" position of CNEL.

\section{E. ENCHANT RESOURCES LTD. v. DYNEX PETROLEUM LTD. ${ }^{33}$}

In Enchant Resources Ltd. v. Dynex Petroleum Ltd., the correct method of calculating an overriding royalty was the issue before the court. In January of 1975, the parties entered into four separate royalty agreements. The royalty provisions, except as to percentage, were identical. The agreements provided as follows:

2(a) The Grantor hereby agrees to pay or cause to be paid to the Grantee, an overriding royalty of $\%$ of the proceeds (subject to the deductions hercinafter referred to) received by the Grantor on the

sale of all petroleum substances produced, saved and marketed from the said lands

3. It is further hereby understood and agreed that the royalty payable under the provisions of this agreement shall be computed and payable on the proceeds received on the sale of petroleum substances produced, saved and marketed from the said lands after deducting the following:

a)

b) The costs of transporting petroleum substances to a plant for processing and/or to the delivery point for the buyer thereof, and

c) The costs of processing or removing impurities from petroleum substances, and

d) The costs of distribution and compressing.

Enchant Resources Ltd. objected to its royalty being reduced by Alberta cost of service on the basis that Alberta cost of service was not contemplated by the parties when they entered the royalty agreements. It argued that Dynex was only entitled to deduct transportation cost to the buyer's delivery point (at the Dynex gas plant gate) whereas the Alberta cost of service deducted from the Alberta border price paid to Dynex included NOVA services charges from the gas plant to the border, as well as take-or-pay financing charges and other expenses associated with TCPL.

Mr. Justice Holmes viewed the issue as whether or not the Alberta cost of service is a proper deduction from "the proceeds received" by Dynex on the sale of petroleum substances produced, saved and marketed. He held that, at the time the royalty agreements were signed, it was the intention of both parties that the word "proceeds received" in clauses 2 and 3 of the agreements meant "actual cash price received from a 
buyer by Dynex." Therefore, the plaintiff's claim that the entire cost of service must be added back into the price received by the defendant was dismissed.

The plaintiff also sought a declaration that take-or-pay interest charges should be exempted from the calculation of its royalty as being "unfair and inequitable" to overriding royalty holders such as Enchant. The basis of this argument appears to be that the take-or-pay prepayments were made directly to Dynex and Enchant received no benefit. This claim was also dismissed by Mr. Justice Holmes as follows:

It was open to Enchant at the time to bargain for a share of any take-or-pay payments but it did not. I am therefore not persuaded that it is unfair or inequitable for take-or-pay carrying charges to be included in the Alberta Cost of Service insofar as Enchant is concerned. I agree with the APMC in its determination 77-15 that take-or-pay carrying charges should be characterized as "a cost attributable to the acquisition of gas" and having regard to the regulatory history with respect to Alberta Natural Gas Marketing take-or-pay costs are properly included in the ACOS.

Enchant also sought a declaration that its royalties should be calculated on the average price received by Dynex on all gas sales. Enchant apparently argued that lower prices were received from those lands in which the plaintiff held a lower royalty interest. This claim was also dismissed by Mr. Justice Holmes. He held that the royalty agreement between Dynex and Enchant did not require or contemplate any blending or averaging of the prices received by Dynex from lands covered by different gas purchase agreements.

Although unsuccessful on its major claims, the plaintiff successfully recovered an award of interest for an improper debit for mineral taxes made by the defendant in calculating the overriding royalty.

\section{F. KELES PRODUCTION COMPANY LTD. v. HUSKY OIL OPERATIONS LTD. ${ }^{34}$}

Husky farmed out $50 \%$ of its interest to Keles under a farmout agreement dated December 1,1986 . The interest of Husky was burdened by a $15 \%$ gross overriding royalty. The farmout agreement contained the following provision:

\section{Encumbrances on Interest}

The Farmee hereto recognizes that the Farmout Lands are encumbered by a nonconvertible $15 \%$ Gross Overriding Royalty pursuant to an Agreement dated January 2, 1967 between Canadian Superior Oil Ltd. and Husky Oil Operations Ltd. The Farmee acknowledges that it has examined such agreement and related documents and hereby agrees to assume and accept such obligations on behalf and in place and stead of Husky Oil Operations Ltd. on the Farmout Lands. For greater clarity, Farmee is completely responsible for payment of the hereinabove mentioned override in addition to any override granted to Farmor by the terms of this Agreement. 
Notwithstanding the hereinabove mentioned encumbrances, if the interest of any party in the Farmout Lands is now or hereafter shall become encumbered by any royalty, excess royalty, overriding royalty, production payment or other charge of similar nature, other than the royalties as set forth under the terms of the lease, such additional royalty, excess royalty, overriding royalty, production payment or other charge of similar nature shall be charged to and paid entirely by the party whose interest is or becomes thus encumbered.

Keles contended that the overriding royalty should be paid by the parties in proportion to their working interests, and if not, the agreement should be rectified. Husky responded that, under the express terms of the agreement, Keles was to pay the entire gross overriding royalty out of its share of production, and the written agreement properly reflected the agreement of the parties.

McBain J. reviewed the negotiating history and commercial context of the agreement and found that the language of the agreement was clear and unambiguous. The meaning to be given to the words of the agreement was not excluded by the context and made sense in view of the factual matrix of the agreement. Therefore, the gross overriding royalty was the sole responsibility of the plaintiff and its action was dismissed. 


\section{G. PRISM PETROLEUM LTD. et al. v. OMEGA HYDROCARBONS LIMITED ${ }^{35}$}

In this case, Omega Hydrocarbons Ltd. ("Omega") held the oil rights in certain lands. The plaintiffs, Prism Petroleum Ltd. ("Prism"), held all rights to natural gas. The primary issue before the Court was the ownership of evolved gas produced by Omega in the course of drilling and producing oil.

The facts are complicated and a number of relevant agreements were reviewed by Mr. Justice Egbert. The essential facts, however, are as follows: In 1964, the Provost Gas Unit (the "Gas Unit") was established. Prism was the operator of the Gas Unit since August 1,1987 . Operating within the boundaries of the gas unit were two oil units operated by Omega: the North Provost Viking oil unit and the South Provost Viking oil unit. Omega had drilled a number of wells that produced oil, and natural gas in conjunction with the oil. Omega had entered into a contract with TCPL to sell the gas. The plaintiffs sued for compensation for gas produced by Omega. Omega took the position that gas produced in conjunction with oil was evolved gas (gas that due to a decrease in pressure, was no longer in solution) and, therefore, belonged to it as the owner of the petroleum rights. The plaintiffs alleged that the gas was in fact owned by the working interest owners in the Gas Unit.

Egbert J. analyzed the various contracts pursuant to which Omega acquired its interest in the oil rights. He held that Omega acquired its interest subsequent to the formation of the Gas Unit and, therefore, what Omega acquired was limited to what remained following the dedication of rights to the Gas Unit. Mr. Justice Egbert states: ${ }^{36}$

\footnotetext{
The structure of the gas unit agreement is such as to give the gas unit basically all petroleum substances excepting only those that qualify under the definition of oil. In this regard, I focus my intention on the second portion of the definition of oil which, to repeat, says that "Oil" means all other hydrocarbons regardless of gravity that are or can be recovered in liquid form from the Viking zone through a well by ordinary crude oil production methods.
}

The focal point of the issue, therefore, was a determination of when a hydrocarbon is "recovered." Omega argued that the hydrocarbons were recovered in the reservoir and Prism argued that recovery occurs at the surface. Justice Egbert concluded that it was the intention of the parties that recovery occurs at the surface. Therefore, the plaintiffs were held to be the owners of the gas produced by Omega in conjunction with oil from the wells located on the lands. The Privy Council decision in Borys v. Canadian Pacific Railway and Imperial Oil Limited ${ }^{37}$ was distinguished on the basis of the particular wording in the Gas Unit Agreement. A subsidiary argument based on s. 148(3) of the Mines and Minerals Act (now s. 90(2) of the Mines and Minerals Act) was rejected by Justice Egbert. This section limits the meaning of natural gas from lands leased from the Crown to what is produced from wells which, in the opinion of the Energy Resources Conservation Board, initially have a gas/oil ratio of 10,000 cubic feet/barrel or higher. 
Justice Egbert held that the purpose of this section is to define for conservation purposes what is a gas well and what is an oil well and has "nothing whatsoever to do with determining ownership of oil and gas." ${ }^{38}$ Justice Egbert also rejected the arguments of Omega based on estoppel and limitations. With respect to limitations Justice Egbert held that the applicable limitation period was s. 18 of the Limitation of Actions Act which provides for a 10 year limitation period for the recovery of land.

Therefore, the Plaintiffs were successful in overcoming the defences of Omega, and established their ownership of natural gas produced from the Omega wells. It was, however, in the words of Justice Egbert, a "pyrrhic victory. ${ }^{139}$ The successful plaintiff in this case ended up having a net judgment entered against them for over $\$ 2,000,000$. Mr. Justice Egbert held that the plaintiffs were required to pay their share of costs involved in producing the solution gas. If not obligated to pay their share of costs, the plaintiffs would be unjustly enriched. The solution gas apparently had a value of $\$ 2,759,813$, whereas the court held that the plaintiff's share of costs was in the order of $\$ 5,966,900$. Judgments were entered accordingly.

A question arises as to whether it is fair for one whose gas is being produced and processed without his consent, to be held accountable to pay for the costs of the unauthorized production, especially where those costs exceed the price received. It seems to the writer that, at best, the costs should only be set-off against the amount actually received for the case. Furthermore, the amount of costs ascribed to the plaintiffs appears excessive. The decision is under appeal.

\section{ENVIRONMENTAL REGULATION}

There have been several recent decisions dealing with the Environmental Assessment and Review Process Guidelines Order $^{40}$ which were passed under the provisions of the Department of the Environment Act. ${ }^{4 !}$ Generally, the EARP Guidelines require all federal departments and agencies that have a decision making authority for any initiative, undertaking or activity that may have an environmental effect on an area of federal responsibility to initially screen the proposal to determine whether it may give rise to any potentially adverse environmental effects. If the proposal might have a significant adverse effect on the environment, a public review must be undertaken by an environmental assessment panel whose members must be unbiased, free of political influence and possessed of special knowledge and experience relative to the technical, environmental and social effects of any such proposal.

The relevant portions of the EARP Guidelines provide as follows:

2. In these Guidelines:

38. Supra note 35 at 350 .

39. Ibid. at 356.

40. SOR/84-467 (hereinafter the "EARP Guidelines").

41. R.S.C. 1985 , c. E-10. 
initiating department means any department that is, on behalf of the Government of Canada, the decision making authority, for a proposal;

"proponent" means the organization or the initiating department intending to undertake a proposal;

"proposal" includes any initiative, undertaking or activity for which the Government of Canada has a decision making responsibility.

3. The Process shall be a self assessment process under which the initiating department shall, as early in the planning process as possible and before irrevocable decisions are taken, ensure that the environmental implications of all proposals for which it is the decision making authority are fully considered and where the implications are significant, refer the proposal to the minister for public review by a Panel.

6. These Guidelines shall apply to any proposal

(a) that is to be undertaken directly by an initiating department;

(b) that may have an environmental effect on an area of federal responsibility;

(c) for which the Government of Canada makes a financial commitment; or

(d) that is located on lands, including the offshore, that are administered by the Government of Canada.

A. FRIENDS OF THE OLDMAN RIVER SOCIETY v. CANADA (MINISTER OF TRANSPORT) ${ }^{42}$

Further to the discussion of the Federal Court Trial Division and the Federal Court of Appeal decisions cited by Mr. Edie in his "Recent Judicial Developments" paper two years ago, ${ }^{43}$ the Supreme Court of Canada has now ruled on the following issues:

\section{Statutory Validity of the Environmental Assessment and Review Process Guidelines Order}

The Supreme Court decided that the EARP Guidelines create a regulatory scheme that is mandatory in nature and therefore is more like "law" than "guidelines." In response to the appellants' claim that the EARP Guidelines are inconsistent with the duties of the Minister of Transport under the Navigable Waters Protection Act ${ }^{44}$ the Supreme Court held that the minister's duty under the EARP Guidelines is supplemental to his duties under the Act and that there is nothing in the Navigable Waters Protection Act to restrict the minister from considering matters over and above marine navigation concerns in exercising his approval powers under the Act.

(1992), 84 Alta. L.R. (2d) 129 (S.C.C.)

See D.C. Edie, "Recent Judicial Developments of Interest to Oil and Gas Lawyers" (1991) 29 Alta L. Rev. 191 at 205 and 207. 


\section{Applicability of the EARP Guidelines}

The Supreme Court reviewed the process for determining the applicability of the EARP Guidelines to federal undertakings and ministries and then applied the process. It ruled that the Oldman River Dam falls within the scope of the EARP Guidelines as a proposal for which the Minister of Transport is the sole "initiating department" under s. 2 of the EARP Guidelines pursuant to the regulatory duties which fall on the minister under the Navigable Waters Protection Act, particularly under s. 5 thereof. The court then held that the EARP Guidelines do not apply to the Minister of Fisheries due to the lack of a similar regulatory scheme under the Fisheries Act, ${ }^{45}$ of which gives the minister a discretion to request information from any person who carries on or proposes to carry on any work or undertaking that will or may result in the alteration, disruption or destruction of fish habitat. La Forest J. stated that the "discretionary power [under the Fisheries Act] to request or not request information to assist a minister in the exercise of a legislative function does not constitute a decision making responsibility within the meaning of the Guidelines Order.... The Minister of Fisheries and Oceans... has been given a limited ad hoc legislative power which does not constitute an affirmative regulatory duty." ${ }^{16}$

Finally, the court added that the initiating federal department which is applying the EARP Guidelines is not restricted to considering the environmental effect on matters coming strictly under its federal head of power. Rather, in this case, the Minister of Transport must consider the environmental impact of the Oldman Dam on federal jurisdictional areas such as fishing, Indians and Indian Lands as well as his normal area of concern of navigable waters.

\section{Crown Immunity}

The Crown in Right of Alberta had argued that it was not bound by the federal Navigable Waters Protection Act so there could be no decision making responsibility as required under the EARP Guidelines on the federal government's part which could affect the province. Therefore, the EARP Guidelines did not apply to the project. The Supreme Court ruled that the Crown in Right of Alberta is bound by the federal statute by necessary implication, as to hold otherwise would frustrate the intent of the Act. The Alberta Crown, therefore, requires federal statutory authorization to substantially interfere with navigation in the Oldman River, such as by the building of the Oldman Dam. The Navigable Waters Protection Act is the operative federal Act by which such federal authorization must be approved and the Alberta Crown must be bound by it, as it is the only logical procedure for obtaining such approval. 


\section{Constitutional Validity of the EARP Guidelines}

The Crown in Right of Alberta had also argued that the EARP Guidelines are so broad as to render them ultra vires as contravening s. 92 of the Constitution Act, 1867 by giving the government of Canada the ability to regulate the environmental effects of matters within the control of the Province. The Supreme Court of Canada disagreed. It pointed out that both federal and provincial levels of government have the authority and responsibility to legislate with respect to environmental matters but that each environmental concern must be limited to an appropriate head of power in the Constitution Act, 1867. Although local projects would typically be a provincial responsibility, to the extent any project infringes on an area of federal jurisdiction, such as navigation, federal input will be required.

As stated above, the Supreme Court held that once the EARP Guidelines were found to apply, the scope of assessment undertaken by a federal department was not to be confined to the particular head of power to which its involvement could be linked: ${ }^{47}$

... In the case of the [EARP Guidelines], Parliament has conferred upon one institution (the "initiating department") the responsibility, in the exercise of its decision making authority, for assessing the environmental implications on all areas of federal jurisdiction potentially affected. Here, the Minister of Transport, in his capacity of decision maker under the Navigable Waters Protection Act, is directed to consider the environmental impact of the dam on such areas of federal responsibility as navigable waters, fisheries, Indians and Indian lands, to name those most obviously relevant in the circumstances here.

La Forest J. indicated the policy reasoning behind the decision where he stated that an "...environmental impact assessment is, in its simplest form, a planning tool that is now generally regarded as an integral component of sound decision making." ${ }^{18}$ The policy reasoning overrode the strong dissenting opinion of Stevenson $\mathrm{J}$. that the actions of the Oldman River Society prior to its current action were "frivolous and ill-founded" and need not have been considered by the trial judge.

\section{Discretion}

The Supreme Court of Canada ruled that the Federal Court of Appeal had properly interfered with the Federal Court trial judge's discretion not to grant the remedies sought on the basis of unreasonable delay and futility. It held that the respondent Society had been diligent in pursuing all possible levels of governments and courts to have the environmental study ordered and to challenge the legality of the process followed to approve the construction of the Dam. Further, the Province had continued to construct the Dam and refused to surrender to an environmental impact assessment under the EARP Guidelines. There was, therefore, no evidence that the Province had suffered any prejudice from any delay on the part of the Oldman River Society. Finally, the Supreme Court stated that the potential effect of an environmental impact study under the EARP 
Guidelines would not be needlessly repetitive given the studies undertaken by the Province in the past: ${ }^{49}$

... it is not at all obvious that the implementation of the [EARP Guidelines] even at this late stage will not have some influence over the mitigative measures that may be taken to ameliorate any deleterious environmental impact from the dam on an area of federal jurisdiction.

\section{B. SASKATCHEWAN WATER CORPORATION v. CANADIAN WILDLIFE FEDERATION INC. ${ }^{50}$}

At issue in this case was whether the federal Minister of Environment was obligated to mandatorily comply with the EARP Guidelines in exercising his power under the International River Improvements $A c t^{51}$ and require an environmental assessment and review before granting a licence for a project under the Act. The minister had not done this before granting such a licence to the plaintiff. The Federal Court Trial Division ruled that the minister was obliged to follow the EARP Guidelines. ${ }^{52}$ The Federal Court of Appeal dismissed the appeal, commenting that "...the repeated use of the word "shall" throughout ... indicates a clear intention that the [EARP] Guidelines shall bind all those to whom they are addressed, including the Minister of the Environment himself." ${ }^{.33}$

\section{EASTMAIN BAND v. ROBINSON ${ }^{54}$}

Again, the court (this time the Federal Court Trial Division) was dealing with a situation where a federal minister did not see fit to order an environmental and social impact study with respect to a proposed project pursuant to the EARP Guidelines. The Court discussed the Saskatchewan Water Corporation case as standing for the principle that the minister's failure to act in accordance with his duty to undertake an assessment and review to determine any potentially adverse environmental effects before issuing a licence under the International River Improvements Act was a breach of duty entitling the applicants to certiorari and mandamus.

The court also discussed Friends of the Oldman River Society v. Canada ${ }^{55}$ at length and stated that the court in Oldman concluded that the "alteration, disruption or destruction of fish habitat by the project fell within an area of federal responsibility and was an "initiative, undertaking or activity" within the sense of the word "proposal" as defined under the EARP Guidelines."

The court held that the federal government's fiduciary obligation toward the native people, as exercised by the Minister of Indian Affairs and Northern Development, includes 
an obligation to apply the EARP Guidelines and initiate a study where a request had been forwarded to each of the respondent ministers by the applicant native band to determine the ministers' respective intentions regarding an assessment of one of the projects in question. The court held that such fiduciary duty is one enforceable by an order of mandamus. However, the court did not concur with the applicant that mandamus should be available to compel the minister to initiate a public review over and above the environmental impact study. Rouleau J. stated that the question as to whether "public concern dictates the desirability of a public review is a matter left to the discretion of the minister. The question to be determined is whether the minister proceeded on a wrong principle, irrelevant consideration, or otherwise acted beyond the scope of his authority. "I56 If not, the court cannot interfere with the minister's discretion to determine whether a public review is warranted or not. Finally, the court ruled that it did not have the power to suspend work on the project until the outcome of a public review.

\section{QUEBEC (ATTORNEY GENERAL) v. CANADA (NATIONAL ENERGY BOARD) $)^{57}$}

In approving several applications by Hydro-Quebec for licences to export electricity to the States of New York and Vermont, the National Energy Board ("NEB") imposed several licence conditions. One condition was that any projects to be undertaken for the construction of production facilities required by the contracts underpinning the licences were to be the subject of environmental impact studies pursuant to the EARP Guidelines. The NEB believed that it was required by the EARP Guidelines to require such studies.

The Federal Court of Appeal ruled that the NEB exceeded the limits of its jurisdiction and authority as it has no power over the construction of such projects but only for the export of the resource. Marceau J. stated "...the carrying out of these projects is not in any way connected with the exports, which will be supplied by the network itself and which only affect a small fraction of its total capacity. ${ }^{158}$ Marceau J. further commented that: ${ }^{59}$

It is clear that the construction of electrical energy production facilities raises serious environmental questions which must be considered and resolved, but those questions are the responsibility of other authorities besides the Board, and those authorities have no need of the Board's support in order to act, nor in any case is it the Board's function to lend such support.

Under the terminology in the EARP Guidelines, the NEB never was the "initiating department" with respect to the construction projects as it did not have the jurisdiction to properly consider the construction projects in the first instance. The court stated that the NEB only had jurisdiction to consider the environmental consequences of the export from Canada of power produced in Canada. 


\section{E. SASKATCHEWAN ACTION FOUNDATION FOR THE ENVIRONMENT INC. v. SASKATCHEWAN (MINISTER OF THE ENVIRONMENT AND PUBLIC SAFETY ${ }^{\circ 0}$}

The appellant in this case was a non-profit corporation established to "promote the protection of the environment through the taking of whatever lawful action it might see fit." It made several requests to the Saskatchewan Minister of the Environment and Public Safety for all documents in the minister's possession relating to each of four major projects in the Province of Saskatchewan which were at various stages of construction. The four projects were the Rafferty-Alameda Dam Project, the Island Falls Dam Construction Project, the Meadow Lake Pulp Mill Project and the Saferco Fertilizer Plant Project. When the minister did not reply to its letters, the appellant made an application for an order compelling the minister to produce the documents which it had demanded. The minister subsequently issued an order pursuant to s. 7 of the Environmental Assessment $A c t^{61}$ forbidding disclosure to the appellant or any other party of the documents and information. Subsequently, the appellant's motion went before a chambers judge but was adjourned. Prior to the adjourned motion being heard, the minister issued a second order pursuant to the Act providing that the documents with respect to the Island Falls Project and the Saferco Fertilizer Project would be released for public inspection, with certain exceptions. The appellant's motion was subsequently argued and dismissed. It appealed to the Saskatchewan Court of Appeal.

The main issue in this case was summarized by Sherstobitoff J.A. as being: ${ }^{62}$

\footnotetext{
Whether and to what extent members of the public have a right of access to documents in the possession of the Minister of the Environment and Public Safety, Saskatchewan, documents related to projects or developments which have undergone, or are undergoing, or are liable to undergo, assessment under the provisions of the Environmental Assessment Act.
}

In analysing the above issue, the court reviewed the report of the Saskatchewan Environmental Assessment Review Commission (the "Commission"), which had been appointed to review the Environmental Assessment Act and the current Saskatchewan Environmental Assessment and Review process. The Commission's recommendations included an acknowledgement that public participation in the environmental review process must be encouraged and guaranteed and that all information with respect to an environmental review should be public unless confidentiality was "demanded by a proponent for commercial or technical reasons such as when necessary to protect secret processes which permit a continued advantage over competitors in their industry, etc."

Sherstobitoff J.A. then reviewed the Act, and held that it had three purposes: 
1. to ensure that there are adequate and acceptable safeguards and protections for the environment in respect of all new developments (as defined in the Act) within the Province;

2. to ensure that there will be someone with adequate powers to oversee the protection of the environment; and

3. to engage the public in ensuring environmental protection.

With respect to this third purpose, he pointed out that s. 11 of the Act requires that environmental impact statements submitted by proponents of developments to the minister and subsequent departmental reviews, be available for "public inspection." The court stressed that the Act contains the concept that meaningful public involvement is fundamental to the entire process. The court referred to the duties of the minister to make information available to the general public with respect to reviews and to the role of the minister under the Act as one of a "watchdog" for environmental concerns, which requires the minister to hear the views of opponents as well as proponents of a project. In other words, the minister must potentially listen to views opposed to the grant of ministerial approval.

Sherstobitoff J.A. then discussed the overall scheme of the Act with respect to applications by proponents and the review of such applications by the minister and his staff. He stated: ${ }^{63}$

The provisions of the Act are unequivocal in their meaning: only after receiving public input on any proposed development can the minister make the decision that he is required by law to make. The scheme of the Environmental Assessment Act is unmistakenly adversarial; it allows for a proponent, and for an opponent or opponents; and the minister, as decision maker, is placed squarely in between.

Public consultation and informed debate have been made an integral part of the environmental assessment process with a view not only to decision-making which is more environmentally sound, but also that which is more publicly acceptable. Such informed public participation is possible only if all participants are given full access to all available information except that specifically exempted by statutory authority.

Therefore, the court ruled that the appellant had a statutory right of access to all information and documents it sought and that the minister had a duty to make such information available.

The court then turned to the question of whether the minister has the authority to determine that the project is a "development" under the terms of the Act. The court decided that the Act did not expressly confer the right to determine whether or not a project is a "development" on the minister but that such decision, as in all cases of statutory interpretation, must lie with the courts. The court ruled that the decision of the minister that the Island Falls Project and the Saferco Fertilizer Project were not 
developments under the Act was not binding and therefore, for the purposes of the application before the court, the appellant could rely on the provisions of the Act to demand access to the documents at issue. Further, with respect to the question of how long the public's right to access information under the terms of the Act lasts, the court decided that public's right to information continues as long as a development remains subject to it.

\section{F. R. v. RICHARD BREMNER AND BREMNER ENGINEERING AND CONSTRUCTION LIMITED ${ }^{64}$}

Judge Fradsham found the defendants guilty of violating s.36(3) of the Fisheries Act ${ }^{65}$ for their acts of dumping silt-laden water into Spring Creek near Canmore. In dealing with the question of sentence, he referred to the dissenting reasons of McClung J.A. in $R$. v. Harte $^{66}$ with respect to the joint sentencing submissions submitted by counsel for each of the Crown and the two accused. McClung J.A., speaking for the entire court regarding sentencing, stated that notwithstanding the submission of sentencing proposals by counsel, the judge still remains constitutionally obliged to impose the sentence which the judge feels is merited. McClung J.A. stated in Harte that the constitutional obligation of the judge "is not to approbate one [a sentence] bargained in the judge's absence." Judge Fradsham then stated that pollution is a serious concern which should be addressed harshly by the courts as enunciated in several cases, including $R$. v. United Keno Hill Mines $^{67}$ and $R$. v. Panarctic Oils Ltd. ${ }^{68}$ and he cited the maximum first offence fine under the Fisheries Act of $\$ 50,000$ as evidence of Parliament's clear intent to deter such offences.

Judge Fradsham then referred to the court's obligation to base sentences with respect to environmental offences not just on what damage was actually caused but more importantly on what damages might reasonably have been caused by the defendants' acts. In speaking for the need for deterrence as being of the utmost concern, he stated: ${ }^{69}$

The accused in this case undertook an activity for profit and chose to use a societal resource (Spring Creek) as a means to economically deal with a by-product of their construction efforts. In essence they chose to impose part of their burden of their business endeavour on all Canadians. When confronted with the offence they were committing, they did not address the root of the problem and in at least one instance deliberately continued to commit the violation. The contract undertaken by the accused was a valuable one - the decisions of the accused were motivated only by money. There was no real effort either to understand or to comply with their lawful obligations under the Fisheries Act.

In passing sentence, the court reflected on various decisions which suggested that while uniformity in sentencing is important, uniformity in principles is of a higher importance.

o. (1991), 83 Alta L.R. (2d) (Alta Prov. Ct.).

65. R.S.C. 1985 , c. F-14.

s6. (18 June 1991), Appeal Doc. 12569 (Alta C.A.) [unreported].

67. (1980), 10 C.E.L.R. 43 (Y.T. Terr. Ct.).

68. [1983] N.W.T.R. 143, 12 C.E.L.R. 78, 3 F.P.R. 429, 43 A.R. 199 (N.W.T. Terr. Ct.).

69. Supra note 64 at 130 . 
The judge disagreed with the joint view of counsel that the appropriate range of sentence was a fine in the range of $\$ 2,000$ to $\$ 5,000$ and ordered the corporate accused to pay a $\$ 10,000$ fine and the individual to pay a $\$ 2,000$ fine.

\section{G. R. v. BATA INDUSTRIES LTD. ${ }^{70}$}

See the discussion, infra under Director's Liability.

\section{DIRECTOR'S LIABILITY}

The directors of corporations are becoming increasingly exposed to a wide range of potential liabilities. While there have been a number of recent decisions relating to directors' liabilities, the following two cases, while not oil and gas cases per se, are significant because they concern two topical areas for oil and gas companies. The first case deals with directors' liabilities for environmental offences and the second case deals with directors' liability in dealings with trust monies.

\section{A. R. v. BATA INDUSTRIES LTD."}

The defendant corporation and three of its officers and directors were charged with several offences under the Environmental Protection $\mathrm{Act}^{72}$ and the Ontario Water Resources Act. ${ }^{73}$ The charges alleged that the corporate defendant caused or permitted the discharge of liquid material waste from its shoe manufacturing plant into the ground so that the groundwater could be impaired. The defendants argued that there was no evidence of a discharge or impairment and that, in any event, they had exercised due diligence.

The Ontario Court of Justice - Provincial Division held that there was a discharge of waste material and that the defendant corporation was the source of the discharge. Further, with respect to the issue of impairment of the quality of the ground water, the court ruled that it is enough that the discharge may impair the ground water to find impairment present. Therefore, having found that the actus reus of the offence pursuant to s. 16(1) of the Ontario Water Resources Act had been established, the court then turned to the due diligence defence raised by the defendants.

Judge Ormston noted that the defence of due diligence had changed from the beginning of the trial to the time when he was faced with making his decision. Initially, the defendants only had to raise a reasonable doubt on the issue of due diligence. However, owing to the decision of the Supreme Court of Canada in Wholesale Travel et al v. Her

70.

(7 February 1992), Belleville 92-00049 (Ont. C.J.-Prov. Div.) [unreported]. All subsequent references are to the unreported decision. The case is now reported at (1992), 70 C.C.C. (3d) 394 (Ont. Court of Justice - Prov. Div.) The authors have been advised that an appeal of sentencing is pending.

lbid.

R.S.O. 1980 , c. 141.

R.S.O. 1980 , c. 361 . 
Majesty the Queen, ${ }^{74}$ the defendants were required to establish the defence of due diligence on a balance of probabilities. The court stated the test that the defendants had to meet: ${ }^{75}$

\footnotetext{
Once the actus reus is established beyond a reasonable doubt, the defence of due diligence is open to the defendants. The defendants must establish on the balance of probabilities that they were duly diligent, that is they must establish that they exercised all reasonable care by establishing a proper system to prevent a commission of the offence and by taking reasonable steps to ensure the effective operation of the system. The availability of the defence to a corporation will depend on whether such due diligence was taken by those who are the directing mind and will of the corporation, whose acts are therefore in law, the acts of the corporation itself.
}

The court then walked through a lengthy history of the problems surrounding the storage of the liquid waste on the grounds of the Bata plant, including the efforts made by a disposal firm to try to get the defendant to contract to dispose of the waste. The accused, Weston, the onsite manager and a director of the corporation, had ignored the advice of the supervisor whom he had put in charge of the environmental concerns at the plant and delayed the implementation of a waste disposal process until the day that the inspectors arrived from the Ministry of the Environment. In fact, when the supervisor informed Weston that the quote for removing the waste was $\$ 56,000$, Weston reacted by instructing the supervisor to get an alternate quote. The supervisor obtained another quote of $\$ 28,000$. At that point, Weston instructed the supervisor to hire the company that provided the lower quote. However, shortly thereafter that company advised that it would not be able to honour the agreement to clear the waste. Immediately prior to Weston's transfer to a different country from his post as general manager of the Ontario plant, he allocated the amount of $\$ 100,000$ for the removal of the waste in an internal budget.

Judge Ormston then reviewed the practices of Invar Manufacturing, formerly Bata Engineering, a sister division to the shoe manufacturing business carried out by the defendants. He discussed the extreme measures that Invar had taken to address environmental concerns and problems, including the training of people with respect to such environmental concerns and the practice of having waste hauled away on a regular basis. Finally, he found that Bata Industries Ltd. had not established that it had exercised all reasonable care and therefore the defence of due diligence failed.

Judge Ormston then went through a detailed analytical review of the provisions of the Environmental Protection Act and the regulations passed thereunder dealing with waste generation facilities. The defendants had raised the argument that the provisions of the Ontario Water Resources Act and the Environmental Protection Act requiring a person who has caused or permitted the discharge of a material or of a contaminant to notify the ministry forthwith are a violation of their right to silence and therefore constitute an infringement of the principles of fundamental justice and a deprivation of the right to life, liberty and security of the person as guaranteed by s. 7 of the Charter. In upholding the

75. Supra note 70 at 9, from Regina v. The City of Sault Ste. Marie (1978), 85 D.L.R. (3d) 161 (S.C.C.). 
validity of s. 16(2) of the Ontario Water Resources Act and s. 14(1) of the Environmental Protection Act, Judge Ormston held that he was bound by the decision of Browne, J. in Her Majesty the Queen v. Weils Food Processing Ltd. and Henry Weil ${ }^{76}$. In that case, Browne J. stated: ${ }^{77}$

I find that the notice sections under the Environmental Protection Act and the Ontario Water Resources Act are not saved by Section 1 of the Charter. However like Galligan, J.A. in Ellis-Don, supra I am of the opinion that it is not necessary to render the notice section in the respective Acts of no force and effect. As the sections are unconstitutional only to the extent that notice can be used in proceedings against the giver of notice, the sections should be interpreted as providing that the notice not be used against the giver.

Finally, the court turned to the issue of directors' liability. Judge Ormston reviewed the provisions of the Ontario Business Corporations Act $1982^{78}$ and the Canada Business Corporations $A c t^{79}$ and stated that the principle to be followed in this case was that the duty to take "all reasonable care" is a question of law, but whether all reasonable steps were taken is a question of fact. He found that the concepts of the law of negligence are an appropriate and acceptable standard to be applied when interpreting regulatory statutes such as the ones in issue. He stated that the defendants' argument essentially involved two questions:

(i) The foreseeability question. Ought the directors, given the nature of the business of the corporation reasonably foresee a likelihood of discharge?

(ii) The standards question. Did they meet the reasonable precautions standards of their industry? ? $^{\text {o }}$

In answering the defendants' assertion that the onus of disproving due diligence should fall on the Crown, the judge referred to the judgment of Dickson J. (as he then was) in Regina v. The City of Sault Ste. Marie: ${ }^{81}$

The correct approach in my opinion, is to relieve the Crown of the burden of proving mens rea ... and to the virtual impossibility in most regulatory cases of proving wrongful intention. In a normal case, the accused alone will have knowledge of what he has done to avoid the breach and it is not improper to expect him to come forward with the evidence of due diligence. This is particularly so when it is alleged... that pollution was caused by the activities of a large and complex corporation.

The judge noted that there was very little guidance from Canadian precedents as to the legal standards of directors with respect to environmental offences, and therefore he turned

\footnotetext{
76. (24 June 1991), (Ont. Court of Justice - Gen. Div.) [unreported].

77. Ibid.

78. S.O. 1982, c. 4.

79. S.C. $1984-75-76$, c. 33.

80. Supra note 70 at 31 .

8I. Supra note 75 at 181 .
} 
to the statements in the American case of Michigan Natural Resources Commission v. Arco Industries: ${ }^{82}$

The parties in this action have asked the court to clarify a more exact legal standard by which corporate officers and directors may be held personally liable.... A court under the circumstances before me should weigh the factors of the corporate individual's degree of authority in general and specific responsibility for health and safety practices, including hazardous waste disposal. These factors should be applied in order to answer the question of whether the individual... could have prevented or significantly abated the hazardous waste discharge that is the basis of the claim...

This court will look to evidence of an individual's authority to control, among other things, waste handling practices - evidence such as whether the individual holds the position of officer or director, especially where there is a co-existing management position: distribution of power within the corporation, including position in the corporate hierarchy and percentage of shares owned. Weighed along with the power factor will be evidence of responsibility undertaken for waste disposal practices, including evidence of responsibility undertaken and neglected, as well as affirmative attempts to prevent unlawful waste disposal.

As power grows, the ability to control decisions about waste disposal increases, and second, as one's stake in the corporation increases, the potential for benefiting from less expensive (and less careful) waste disposal practices increases as well.

Judge Ormston then attempted to establish a minimum profile against which the directors' liability should be measured. In so doing, he asked himself the following questions: ${ }^{83}$

(a) Did the Board of Directors establish a pollution prevention "system" as indicated in Regina v. Sault Ste. Marie, i.e. Was there supervision or inspection? Was there improvement in business methods? Did he exhort those he controlled or influenced?

(b) Did each Director ensure that the corporate officers had been instructed to set up a system sufficient within the terms and practices of its industry of ensuring compliance with environmental laws to ensure that the officers report back periodically to the Board on the operation of the system, and to ensure that the officers are instructed to report any substantial non-compliance to the Board in a timely manner?

He stated: ${ }^{84}$

Within this general profile and dependent upon the nature and structure of the corporate activity, one would hope to find remedial and contingency plans for spills, a system of ongoing environmental audit, training programs, sufficient authority to act and other indices of a pro-active environmental policy. 
Judge Ormston found that Thomas G. Bata, the Chief Executive Officer of the Bata Shoe organization and of Bata Industries Ltd. located in Toronto, had evidenced that he was aware of his environmental responsibilities and responded to any matters that were brought to his attention promptly and appropriately. Accordingly, Mr. Bata met the burden of establishing due diligence and was not guilty of the offences charged.

The judge then analyzed the potential liability of the accused Marchant, who was the president and a director of Bata Industries Ltd. The court stated that the evidence established that for at least the last six months of the time alleged in the charges, Marchant had personal knowledge of the environmental problems. Judge Ormston stated that: ${ }^{85}$

In the circumstances, it is my opinion that due diligence requires him to exercise a degree of supervision and control that "demonstrates that he was exhorting those whom he may be normally expected to influence or control to an accepted standard of behaviour" ${ }^{186}$.... He had a responsibility not only to give instruction but also to see to it that those instructions were carried out in order to minimize the damage. The delay in clean up showed a lack of due diligence. . . In my opinion, he has not established the defence of due diligence on the balance of probabilities and is therefore guilty as charged.

Finally, the judge turned his attention to Weston, the onsite manager and a director of Bata Industries Ltd. He stated that his responsibilities as the onsite director made him much more vulnerable to prosecution. Weston had demanded the authority to fully control his work environment at Bata before accepting the job. It was the judge's opinion that he had failed to establish that he took all reasonable care to prevent unlawful discharge. Judge Ormston stated that: ${ }^{87}$

...red flags should have been raised in his environmental consciousness when the first quote of $\$ 58,000$ was obtained. Instead of simply dismissing it out of hand, he should have inquired why it was so high and investigated the problem. I find that he had no qualms about accepting the second quote of $\$ 28,000$ and he had no further information other than it was cheaper. This was not an informed business judgment, and he cannot rely upon the business judgment rule, which at its core recognizes that a business corporation is profit oriented and that an honest error of judgment should not impose liability provided the requisite standard of care is met.

The judge went on to state that Weston could not shelter himself behind the advice he received from his subordinate who was to have been in charge of the environmental concerns at the plant. Most importantly, the judge found that such subordinate was not given the authority to expend any amount with respect to the clean up of the environmental waste on his own, but rather, he required the approval of Weston. On this point the court stated that: ${ }^{88}$

86. R. v. City of Sault Ste. Marie, supra and R. v. Southdown Builders Lid. (1981), 57 C.P.R. (2d) 56 (Ont. Co. Ct.). 
As the "on-site" director Mr. Weston had a responsibility in this type of industry to personally inspect on a regular basis ie. "walk-about". ... He had an obligation if he decided to delegate the responsibility to ensure that the delegate received the training necessary for the job and to receive detailed reports from that delegate.

Accordingly, Weston was found guilty of the offence pursuant to s. 75 (n) of the Ontario Water Resources Act.

In a separate sentencing proceeding, ${ }^{89}$ the court fined each individual director the amount of $\$ 12,000$, and fined the corporate defendant $\$ 60,000$ and placed it on probation for a two year period. The terms of the probation included, among other things, that it was to publish on the front page of the Bata Newsletter for international distribution the facts leading to the conviction of the corporation and the named directors along with the details of the penalties and the terms of the probation. In addition, the corporation was not to indemnify either of Weston or Marchant for the fines imposed. No detailed reason for the lack of indemnity was given.

\section{B. AIR CANADA v. $M \& L$ TRAVEL LTD., MARTIN AND VALLIANT ${ }^{90}$}

In 1973, Martin and another individual incorporated the respondent corporation to carry on business as a travel agency. After the other individual withdrew from the business, the respondent Valliant became a shareholder and director of the corporation. In 1978, when Valliant invested in the corporation, he borrowed his funds from the Royal Bank, agreeing to repay the loan in the monthly instalments drawn from the corporation's general account. The corporation became a member of the International Air Travel Association ("IATA") with the sponsorship of Air Canada under the terms of two written agreements which the corporation entered into with IATA and Air Canada. The corporation was to hold all money collected for air passenger transportation in a separate trust account as such funds were to be the property of Air Canada until they were satisfactorily accounted for. Twice a month the corporation was required to report sales of Air Canada tickets and to remit to Air Canada the monies received from customers which it was holding in trust for Air Canada. In fact, the corporation did not keep the funds from the sale of Air Canada tickets in separate trust accounts but rather they were intermingled in the corporation's general operating account with funds received from all sources.

Subsequently, the corporation was granted an operating line of credit in the amount of $\$ 15,000$ from the Provincial Bank. Under the terms of this loan agreement, both Martin and Valliant personally guaranteed the loan. Both executed the documents on behalf of the corporation in favour of the bank, authorizing the bank to remove any monies at any time owing on the loan from the general account of the corporation. The corporation's general operating expenses, the interest due on the loan from the Provincial Bank and the monthly cheques owing to the Royal Bank of Canada in respect of the personal loan of 
Valliant were all issued by the corporation out of its general account. In 1979, the corporation began experiencing financial difficulties and each of Martin and Valliant became suspect of the other's actions with respect to the finances of the corporation. Each of Martin and Valliant gave the Provincial Bank different instructions with respect to a cheque payable to Air Canada in respect of monies owing to Air Canada. As a result, the bank refused to negotiate cheques made out to Air Canada because of such previous stop payment instructions of Martin and Valliant. In the result, Air Canada was never paid the amount of $\$ 25,079.67$ which was owing to it in this regard. Despite attempts by each of Martin and Valliant to pay the Air Canada indebtedness, the bank would not honour cheques as it was aware of the financial difficulties of the corporation as well as the inability of Martin and Valliant to come to an agreement as to how the corporation should carry on. Subsequently, the bank issued a demand notice to Valliant and the corporation. The following day, it exercised its rights under the terms of the loan documents with the corporation and Martin and Valliant as guarantors. It withdrew $\$ 15,184.11$ from the corporation's account and applied the funds to the demand note given when the original loan documents were entered into among the parties. As a result, there was only $\$ 1,000.00$ left in the corporation's account.

Air Canada sought judgment against the corporation and against Martin and Valliant personally. The trial judge found that the corporation should be held liable but that the individual respondents were not liable. Air Canada appealed to the Ontario Court of Appeal.

Air Canada's position with respect to Martin and Valliant at trial was that each of them were trustees de son tort; a person who takes it upon himself to possess and administer trust property for beneficiaries and who becomes a trustee by imposition of law. The trial judge held that Martin and Valliant were not trustees de son tort as there was no assumption by Martin and Valliant of such trust. The Ontario Court of Appeal upheld the trial judge's decision on this point agreeing that neither Martin nor Valliant had assumed legal control or possession of the trust funds as such funds were at all time administered in the name of the corporation.

The Ontario Court of Appeal then addressed the issue of whether or not Martin and Valliant as directors of the corporation should be held personally liable for the breach of trust committed by the corporation. Griffiths J.A. pointed out that it was significant that the trial judge found that there was a breach of trust by the corporation in failing to take steps to protect the interests of Air Canada, as there would be no issue of potential liability of Martin and Valliant as directors if the corporation had been found guilty only of a breach of contract rather than a breach of trust. The court reviewed the decision in Canadian Pacific Airlines International v. Canadian Imperial Bank of Commerce ${ }^{91}$ and concluded that "the agreement between Air Canada and the corporation clearly created a trust relationship between them with the result that any monies received by the corporation from the sale of Air Canada tickets were impressed with a trust." ${ }^{\text {"2 }}$ Griffiths J.A. 
pointed out that the personal liability of directors or officers of a corporation involved in a breach of trust in the context involved in this case had not been judicially considered in Canada or England in any of the reported authority, although personal liability had been imposed on directors for breach of trust where the obligation to hold monies in trust was imposed by statute in Canadian decisions. The court then reviewed decisions imposing personal liability on directors for breach of trust in the context of an insurance agent's obligation to maintain insurance premiums in a separate trust account ${ }^{93}$ and in the context of statutory trusts created under mechanics lien legislation. ${ }^{94}$ The court cited several American authorities dealing with similar fact situations to the case at bar.

\section{Griffiths J.A. concluded: ${ }^{95}$}

The trial judge found that the corporation had committed a breach of the trust imposed upon it under the agreement with Air Canada. In that respect, it is clear that Martin and Valliant, as the directing and operating minds of the corporation, used the corporation's general bank account for the funds contributable to the sale of airline tickets and permitted the commingling with other funds received by the corporation. Martin and Valliant also authorized the payment of the funds impressed with trust, in satisfaction of the general expense of the corporation, in payment of salary to Martin and repayment of the personal bank loan of Valliant...

In my view, this is an appropriate case to impose personal liability on Martin and Valliant for the breach of trust. They were the sole owners and operating minds of the corporation. They directed and authorized the deposit of funds from Air Canada sales in the general account without in any way designating those funds as trust funds. They permitted these funds to be intermingled with other funds and they drew cheques on these funds in complete disregard of the trust obligations imposed under the agreement with Air Canada, an agreement which conferred on the corporation which they were the sole shareholders the privilege of selling Air Canada tickets directly to the public. Martin and Valliant permitted Air Canada funds to be placed in a general account which was overdrawn without adequate controls and, in particular, without advising the bank that these funds were trust funds, with the result that these funds were exposed to appropriation by the bank to satisfy the corporation's loan guaranteed by Martin and Valliant. In failing to exercise proper control over the trust funds, both Martin and Valliant received a benefit in that their personal liability to the bank was extinguished.

The Ontario Court of Appeal concluded that each of Martin and Valliant were parties to the conversion of trust funds and were personally liable. The Supreme Court of Canada has granted leave for an appeal of this case but at the time of this paper a decision has not been rendered. However, one does not have to stretch the imagination too far to see that this case could have implications for directors and officers of corporate 567, 104 D.L.R. (3d) 130 (Ont. H.C.J.) aff d (1980), 28 O.R. (2d) 672, 112 D.L.R. (3d) 371 (Ont. C.A.). 
operators under CAPL agreements, having regard to recent developments as to the trust nature of funds held by operators as discussed immediately below.

\section{CREDITORS' RIGHTS}

\section{A. NATIONAL BANK OF CANADA v. ARGYLL ENERGY CORPORATION, ARGYLL RESOURCES LTD. AND PATCO RESOURCES INC. ${ }^{96}$}

In 1988, the Alberta Court of Appeal in Bank of Nova Scotia v. Societe Generale (Canada) Inc. ${ }^{97}$ established that operating revenues held by an operator for the benefit of non-operators were impressed with a trust in favour of the non-operators under the provisions of the 1981 CAPL. The 1990 version of the CAPL addresses the issue of trust explicitly and provides that "notwithstanding that moneys of a Joint-Operator have been commingled with the Operator's funds, the moneys of a Joint-Operator advanced or paid to the Operator, whether for the conduct of operations hereunder or as proceeds from the sale of production under this Operating Procedure, shall be deemed to be trust monies, and shall be applied only to their intended use and shall in no way be deemed to be funds belonging to the Operator, other than in its capacity as the Joint-Operators trustee" (clause 507).

The Sorrel decision left a number of questions unanswered. In Sorrel, the disputed funds were held in a segregated account. What of the situation where joint-operators' revenue was deposited at the operator's bank and commingled with other funds of the operator, and applied by the bank against loans of the operator? Generally, the right to trace funds ends upon payment to a bona fide creditor who does not have notice of the trust. What degree of knowledge was required of the bank before it would be subject to the trust? This was the issue before the court in National Bank v. Argyll.

The facts in this case are not unusual. The plaintiff was the banker for Argyll and knew Argyll operated oil and gas properties on behalf of non-operators. Financial information was provided to the Bank and at least one statement showed Argyll owing joint venture arrears. On January 1, 1990, Coopers \& Lybrand Ltd. was appointed by the Bank to monitor Argyll. By January 18, 1990, the monitor had determined joint venture arrears were approximately $\$ 150,000$. By July 5,1990 , arrears were approximately $\$ 280,000$ and Coopers \& Lybrand Ltd. was appointed Receiver of the Argyll companies. Non-operator production revenue had been applied against Argyll's loans. Relying on Sorrel, the non-operators argued that their revenue was trust funds held by Argyll, this fact was known by the Bank, and accordingly they were entitled to trace through Argyll's account and recover their funds from the Bank.

The Court of Queen's Bench held that actual knowledge on the part of the Bank of the existence of a trust is not required; it is sufficient if the Bank ought to have known of the 
existence of the trust. As a result, the non-operators were able to trace their funds through Argyll's account to the Bank and recover them from the Bank. The court held: ${ }^{98}$

The Bank was aware of the nature of the Argyll companies' business and the fact that the joint venture funds were being deposited with the Bank and commingled with other funds of its customer. It had that knowledge from the outset and it continued to be informed by reason of the reporting mechanisms contained in this agreement with the Argyll companies.

The evidence establishes that the Bank came into possession of financial information on December 18th. 1989 that gave it a clear indication that the joint venture payments were in arrears. The Bank was then sufficiently aware of the situation that it took steps to have Coopers \& Lybrand appointed as a monitor of the Argyll companies on January Ist, 1990. Through the monitor the Bank had full knowledge of the extent of those arrears by January 18th, 1990.

In these circumstances all of the funds are impressed by a trust in favour of the joint venture partners and they are traceable in the hands of the Bank.

\section{B. KARL MUELLER CONST. LTD. v. COMMISSIONER OF NORTHWEST TERRITORIES ${ }^{99}$}

S. 12 of the Interest Act ${ }^{100}$ restricts interest on a judgment to $5 \%$. In these days of lower interest rates, the rate may not seem as inordinately low as it once did. However, s. 11 of the Act restricts the application of s. 12 to the Provinces of British Columbia, Manitoba, Saskatchewan and Alberta and to the Yukon and Northwest Territories. Why a judgment creditor in western Canada should be worse off than others has never been adequately explained.

Justice Wachowich held in the case of Rafael v. Allison ${ }^{101}$ that $\mathrm{s} .11$ and 12 violated the Charter of Rights and Freedoms, as "it is clear that no valid reason exists which could justify the legislation today in view of the Charter."

This issue recently came before the Northwest Territories Court of Appeal in Karl Mueller Const. Ltd. ${ }^{102}$ where the plaintiff succeeded in a contractual claim. The trial judge awarded post-judgment interest of $11.3 \%$. The defendant appealed the whole decision. The Court of Appeal dismissed the appeal, except as to post-judgment interest and the quantum of costs awarded the plaintiff. The respondent (plaintiff) argued that the post judgment interest award should stand because s. 11 of the Interest Act violates s. 15(1) of the Charter of Rights and Freedoms which states: 
15(1) Every individual is equal before and under the law and has the right to the equal protection and equal benefit of the law without discrimination and, in particular, without discrimination based on race, natural or ethnic origin, colour, religion, sex, age or mental or physical disability.

The appellant argued that a corporation cannot invoke s. 15 of the Charter.

The Court of Appeal dealt with the interest issue in an indirect way. It stated: ${ }^{103}$

Even if Karl Mueller Construction were entitled to call to its aid these provisions of s. 15(1) of the Charter it could not, in our opinion, succeed. It would be bound to establish that a judgment creditor in the Northwest Territories seeking an increased rate of interest on its judgment debt, was, somehow, a member of a disadvantaged group. Thus requisite for its invocation of $\mathrm{s}$. 15(1) is impossible for the company to maintain.

The Court of Appeal expressed concern with the adequacy of the record on the constitutionality of ss. 11 and 12 noting that the Charter issue did not emerge until late in the proceedings. The Court of Appeal stated that the constitutionality of ss. 11 and 12 was not at large in the trial, and it was not prepared to finally determine the issue on the appeal. Accordingly, the plaintiff was restricted to interest of 5\%.

C. TRANSGAS LTD. v. MID-PLAINS CONTRACTORS LTD. ${ }^{104}$

The legislation empowering the Minister of National Revenue to collect unpaid taxes over claims of other creditors (both secured and unsecured) has had a litigious history. S. 224(1.2) of the Income Tax Act ${ }^{105}$ initially provided as follows:

Notwithstanding any other provision of this Act, the Bankruptcy Act, any other enactment of Canada, any enactment of a province or any law, where the minister has knowledge or suspects that a particular person is or will become, within 90 days, liable to make a payment...

(b) to a secured creditor who has a right to receive the payment that, but for a security interest in favour of the secured creditor, would be payable to the tax debtor,

the minister may, by registered letter or by a letter served personally, require the particular person to pay forthwith, where the moneys are immediately payable, and in any other case, as and when the moneys become payable, the moneys otherwise payable to the tax debtor or the secured creditor in whole or in part to the Receiver General on account of the tax debtor's liability under subsection $227(10.1)$ or a similar provision.

The Alberta Court of Appeal in Lloyds Bank Canada v. International Warranty Co. ${ }^{106}$ held that s. 224(1.2) as drafted was not sufficient to "expropriate without compensation" 
a secured creditor's interest in the book debts of the borrower. The Saskatchewan Court of Appeal, in the case of Royal Bank of Canada v. Saskatchewan Power Corp., ${ }^{107}$ expressly disagreed with the Alberta Court of Appeal and held the wording to be sufficient.

The federal government responded to International Warranty by amending s. 224(1.2) to add the following:

...and on receipt of that letter by the particular person, the amount of those moneys that is required by that letter to be paid to the Receiver General shall, notwithstanding any security interest in those moneys, become the property of Her Majesty and shall be paid to the Receiver General in priority to any such security interest.

The amended legislation came before the British Columbia Supreme Court in Berg v. Parker Pacific Equipment Sales and Revenue Canada. ${ }^{108}$ That court referred to the legislation as "draconian," but held in favour of Revenue Canada. Robinson J. stated:109

\begin{abstract}
Despite the sympathy with which one must feel for an entity believing itself to have carefully effected a security interest, there is, in my view, no interpretation of this section which can now favour the secured creditor in priority to the claim of Revenue Canada.
\end{abstract}

Revenue Canada's respite was short lived, at least in some parts of Canada.

In Transgas Ltd. v. Mid-Plains Contractors Ltd., s. 224 (1.2) as amended came before the Saskatchewan Court of Queen's Bench. The priority contest was between Revenue Canada, labour and non-labour lien holders, and the Workers' Compensation Board.

The court held that, absent constitutional and Charter implications, Revenue Canada had priority. The drafting holes had been closed; however, a larger problem arose. The court held that s. 224(1.2) was ultra vires the Parliament of Canada. MacPherson C.J. stated as follows: 110

What then is the nature of 224(1.2) of the I.T.A.? It is certainly not remedial from the aspect of the citizen who, by valid provincial law, is legally entitled to certain moneys only to find that these moneys are seized by Revenue Canada, under the authority of this section. Not only is it seized, but the seizure is implemented without warning, without notice, without any right of appeal, without any right to a hearing, and without any remedy which gives him any opportunity to recover the moneys otherwise rightfully his under provincial law. Further, adding insult to injury, in our case about $25 \%$ of the amount seized consists of penalties and interest imposed against Mid-Plains because of its sins, and for which the beneficial owners under provincial law had absolutely no responsibility - still further, the labour lienholders in our case must look at a portion of Mid-Plains debt to Revenue Canada being made up of 
their wage deductions made by Mid-Plains - in effect they are paying twice. It is doubtful if there can be any example of a more serious and obvious encroachment on a provincial power...

I therefore, declare s. 224(1.2) of the I.T.A. to be ulira vires to the extent that it impinges on provincial laws relating to ownership of property pursuant to s. 92(13) of the Constitution Act, 1867, and I specifically declare that the said section is ultra vires and has no application in respect of the trust money which has been paid into court in this matter.

The saga of s. 224 continues.

\section{HAMILTON BROTHERS CORPORATION v. ROYAL TRUST CORP OF CANADA"'I}

In this case, the judgment creditors of Jennifer Petroleums Ltd. sought an order for judicial sale of Jennifer's interest in certain petroleum and natural gas interests under their writs of execution. Jennifer's interests had been assigned by way of s. 177 Bank Act (Canada) $)^{112}$ security to Barclays Bank of Canada as well as Jennifer's entitlement to Alberta Royalty Tax Credits. The Bank opposed an order for judicial sale.

Mason J. first considered the legal characterization of the Jennifer petroleum and natural gas interests. He held that the Jennifer interests were chattels real and not interests in land, and as such, the interests were exigible under s. 5 of the Seizures $A c t^{113}$ subject to the legal effect of the $\mathbf{s}$. 177 security granted by Jennifer. Mason J. referred to Berkheiser v. Berkheiser ${ }^{114}$ and the characterization of a lease as a profit a prendré or an irrevocable license to search for and to win the substances named and concluded: ${ }^{115}$

On the basis of these authorities and the legal nature and characteristics of petroleum and natural gas lease as a profit à prendre for a term certain together with eamed working interests therein which also depend in turn upon the term of the lease and production under the lease, it is my conclusion that the "Jennifer interests" are chattels real.

Therefore, s. 5 of the Seizures Act empowered a judicial sale of the Jennifer interests, subject to the legal effect of the $\mathbf{s}$. 177 security. Justice Mason commented that if the Jennifer interests were interests in land, he would have held they were not exigible under s. 15 of the Seizures Act as the Jennifer interests could not be registered under the Land Titles Act. ${ }^{116}$

R.S.C. 1985, c. B-1.

R.S.A. 1980, c. S-11.

[1957] S.C.R. 387.

Supra note 111 at 53.

R.S.A. 1980, c. L-5. 
The court went on to consider the legal effect of $\mathrm{s}$. 177 security. To the best of the writers' knowledge, there are no cases prior to Royal Trust considering this issue. Mason J. held: ${ }^{117}$

S. 177 security effectively transfers to the bank the 10 percent beneficial interest of Jennifer in the petroleum and natural gas rights and the working interests in those producing wells subject to equities of redemption.

The court refused to order the Jennifer interests sold under the writs of execution. On the evidence, there was no interest of Jennifer available to satisfy the judgments; the interests were fully encumbered in favour of the Bank. Furthermore, an order for sale would jeopardize the assignment to the Bank of Jennifer's ARTC. As a result, the application for judicial sale was refused.

The case is interesting for its characterization of the Jennifer interests and its characterization of $\mathrm{s} .177$ security. The court appears to accept that s. 177 security is akin to a common-law mortgage: a transfer subject to an equity of redemption. ${ }^{118}$

The decision of Mason J. was appealed to the Alberta Court of Appeal by the judgment creditors. The appeal was dismissed as the Court of Appeal held that Mason J. validly exercised his discretion in refusing to order a judicial sale.

\section{TAX}

\section{A. PRECAMBRIAN SHIELD RESOURCES LTD. v. ALBERTA (PROVINCIAL TREASURER) $)^{119}$}

The appellant was the vendor in a carve-out transaction whereby it sold certain producing properties to the purchaser in return for tax losses. The vendor retained possession and control of the properties at all times but the purchaser received all revenues from the properties until it had received the equivalent of the purchase price, interest and a $15 \%$ fee. The purchaser assigned all the revenues and its rights to government grants to its lender, which had wholly financed the purchase. The vendor and the purchaser each applied for the Alberta royalty tax credit pursuant to the provisions of the Alberta Corporate Income Tax Act. ${ }^{120}$ The Provincial Treasurer determined that the two corporations were associated and limited the amount which the parties could claim. The vendor appealed the Provincial Treasurer's decision to the Court of Queen's Bench, which dismissed the appeal. The vendor further appealed to the Alberta Court of Appeal.

Coté J.A. reviewed the provisions of s. 26.1(10) of the Act, which allows the Provincial Treasurer to declare two corporations associated under certain circumstances, including

118. F.R. Foran, R.W. Block, "Enforcement of Oil and Gas Related Security," LESA, 1986 "Coping with Tough Times in the Oil Patch."

119. (1991), 81 Alta L.R. (2d) 152 (Alta C.A.).

120. R.S.A. 1980, c. A-17 [now the Alberta Corporate Tax Act; title amended S.A. 1990, c. 4, s. 2]. 
when one or more transactions, in the opinion of the Provincial Treasurer, artificially increase the Alberta Royalty Tax Credit that may be applied for. In summarizing the transaction before it, he stated: ${ }^{121}$

Here, there is additional Alberta royalty tax credit claimed beyond the ceiling only because a new purchaser has intervened. But that is a purchaser who contributes nothing, risks nothing and gets nothing. It gets but the empty skin of the fruit, and pays nothing for it. Apart from the sale of tax losses, which is quite a separate matter, it would be fair to say that the purchaser merely lends its name.

Where Alberta royalty tax credits are involved, a reasonable person might take the view that what counted was beneficial interests and obligations, not bare trusts or nominee holdings. That being so, the purchaser here might not qualify at all. Therefore, it seems perfectly reasonable to take the view that if this transaction does increase the Alberta royalty tax credit payable (by circumventing the ceiling), it does so artificially.

Accordingly, the Court of Appeal supported the finding of the Provincial Treasurer and dismissed the appeal.

\section{B. MOHAWK OIL CO. v. CANADA ${ }^{122}$}

We refer you to the discussion of the details of this case and the Federal Court Trial Division decision in the 1991 version of this paper. ${ }^{123}$ The trial judge characterized the amount of $\$ 6,000,000$ (U.S.) received by the taxpayer in full settlement for its claim against Phillips Petroleum Company as a non-taxable receipt "akin to a windfall." The Federal Court of Appeal allowed the appeal and reversed the decision of the trial judge. Stone J. reviewed various Canadian and British decisions dealing with the characterization of moneys received in the nature of the moneys received by Mohawk in this situation. He stated that such authorities stand for the rule that it is the character of the receipt from the recipient's point of view that is to be looked at in determining the nature of the payment, not the payor's reason for making the payment. Stone J. stated: ${ }^{124}$

The manner in which a settlement amount has been characterized by the payor in the course of negotiations would seem to be an unsafe test for determining its true nature. The payor's motives for settling a dispute may be many and varied in any given case, and it must be a difficult thing to know precisely what his true motivation may have been, especially where the settlement amount is represented by a lump sum which the documentation does not assign to any particular head of claim. I do not see how the settlement amount can be viewed as being "akin to a windfall" merely because the respondent says it was paid by Phillips to get rid of the claim.

...The evidence is clear that, while Phillips would not agree, the respondent sought from the outset and throughout the settlement negotiations to be made whole including compensation for lost profits and

121. Supra note 119 at 154.

122. (27 January 1992) A-772-90 (F.C.A.) [unreported].

123. See E.A. Leew and M.A. Thackray, "Recent Judicial Developments of Interest to Oil and Gas Lawyers" (1992) 30 Alta L. Rev. 308 at 337.

124. Supra note 122 at 19. 
expenditures thrown away. The record suggests that apart from lost profits, the respondent's other losses were for the cost of the plant itself and certain expenditures which were laid out either to acquire land and install auxiliary facilities or in attempting to make the plant operable. The evidence is also clear that the loss in respect of the land and auxiliary facilities did not materialize because those facilities were required for operating the new plant. As I see it, the settlement amount, of necessity, included compensation for lost profits and expenditures thrown away. Such compensation cannot, in my view, be regarded as "akin to a windfall."

Accordingly, the court upheld the minister's initial reassessment of a portion of the $\$ 6,000,000$ (U.S.) amount as compensation for lost profits and expenditures incurred.

C. TRANSGAS LTD. v. MID-PLAINS CONTRACTORS LTD. ${ }^{125}$

See the review of Transgas Ltd. in the Creditors' Rights section of this paper.

\section{GOVERNMENT REGULATION}

\section{A. RE ANGUS ET AL AND THE QUEEN ET AL 126}

The question at issue before the Federal Court of Appeal was whether the Governor in Council, in passing an Order in Council amending orders of the Canadian Transport Commission and requiring VIA Rail to eliminate certain specified passenger services and drastically reduce others, was obliged to act in compliance with the EARP Guidelines. ${ }^{127}$ The Minister of Transport had commissioned and obtained a document entitled "Changes to the Via Network: Potential Environmental Impact" which did not refer to the EARP Guidelines.

MacGuigan J.A. referred to the decision of Estey J. in the Supreme Court of Canada in A-G Can. v. Inuit Tapirisat of Canada ${ }^{128}$ as setting out the basic principles that:

(1) the power of the Governor in Council in varying or rescinding any rule of the Canadian Transport Commission is "legislative action in its purest form" and that "the discretion of the Governor in Council is complete provided he observes the jurisdictional boundaries" of the National Transportation Act, 1987'29, and;

(2) the legislative power of the Governor in Council may be judicially reviewed if any conditions precedent to the exercise of such power are not observed. Therefore, the court turned to the question of whether the requirements of the EARP Guidelines represent such a condition precedent.

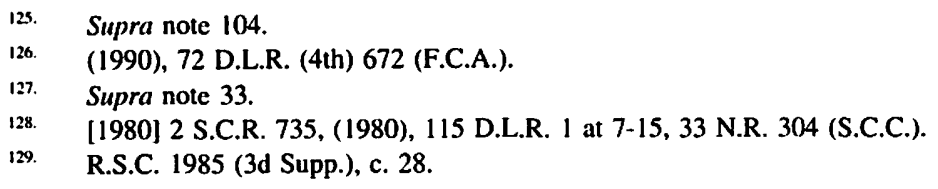


MacGuigan J.A. decided that, although it was quite feasible that the Governor in Council could be viewed as a "board or agency of the Government of Canada" and therefore come under the ambit of the EARP Guidelines, the question was not whether the Governor in Council could be so caught, but rather whether the Governor in Council intended himself to be described in such sense in the EARP Guidelines. The court answered this question in the negative. It ruled that it would take clear language evidencing an intention to include the Governor in Council in "department, board or agency." MacGuigan J.A. stated: ${ }^{130}$

The decision to cut back railway passenger service was, after all, a budgetary decision, and budgets are matters over which Parliament divides on motions of non-confidence. The impugned Order in Council is effectively the implementation of that budgetary decision of April, 1989. It may be thought to be highly desirable that such Orders in Council be submitted to environmental assessment but that sort of desirability can be measured only by considerations of policy beyond the purview of the courts. Courts are confined to the four corners of the enactment. In my view the enactment here, however broadly taken, does not reveal any legislative intention to submit all initiatives, undertakings or activities of the Governor in Council to environmental assessment.

Therefore, the court concluded that the Governor in Council is not required to comply with the EARP Guidelines. On the appellant's contention that, as the Order in Council was made on the recommendation of the Minister of Transport, the minister had exercised the decision making authority which made the Order in Council subject to the EARP Guidelines, the court agreed with the respondent's position that the minister only advised the Governor in Council, which was still the ultimate decision maker. Accordingly, this line of appeal was also dismissed.

It is worth noting that Décary J.A., although agreeing with the result, found that the Governor in Council was bound by the EARP Guidelines as he felt to hold otherwise would frustrate the "beneficent purpose" of the Department of the Environment Act. ${ }^{131}$ He found the Act would be frustrated if the Government of Canada were allowed to distinguish, where Parliament did not, between federal projects that are those of a specific minister and federal projects that are those of Cabinet even acting in a legislative capacity. However, he refused to grant the discretionary remedy of certiorari on the basis of the unexplained delay on the part of the appellants in pursuing the appeal process with respect to the Order in Council and because the evidence filed by the appellants did not even suggest that had the EARP Guidelines been followed, the conclusion of the report with respect to the environmental impact of the VIA Rail cuts which had been tabled in the House of Commons might have been different. 


\section{B. KENNIBAR RESOURCES LTD. v. SASKATCHEWAN (MINISTER OF ENERGY AND MINES) ${ }^{132}$}

For a detailed discussion of the facts in this case we refer to last year's paper. ${ }^{133}$ The Saskatchewan Queen's Bench quashed an order of the Minister of Energy and Mines establishing a four legal subdivision drainage unit for a horizontal oil well on the basis that the order in such case violated the provisions of s.25 of the Oil and Gas Conservation $A c t^{134}$ and therefore constituted an error of law.

On appeal to the Saskatchewan Court of Appeal, Sherstobitoff J.A. ruled, in dismissing the appeal, that it was unnecessary to review the error of law issue which was the basis of the lower court decision. The appeal must fail by virtue of the minister's failure to follow the requirements of procedural fairness. Essentially, the court ruled that ss. 49 and 50 of the Act entitled the plaintiff to have a hearing before the oil and gas conservation board, which did not exist, as a party who claims to be affected by an order of the minister. The minister could not by-pass the provisions of the Act by the neglect of the government, of which he was a part, to appoint a board. Rather, he must follow the same procedures for notice and hearing that the board would be required to follow under the Act. In addition, the court ruled that, as there was no duly appointed board and as the Minster can only delegate its power to conduct hearings to the board and not to his officers and employees, the minister was obligated to conduct such a hearing himself. In the case at bar, as the minister did not give the plaintiff a hearing, the appeal by the minister failed due to his own failure to conduct such a hearing.

\section{SURFACE RIGHTS}

\section{A. GANNON BROS. ENERGY LTD. v. VAN STRATEN ${ }^{135}$}

The respondents were owners of land in respect of which the applicants had been granted certain surface rights by the respondents' predecessor in title. These surface rights included a surface lease of a portion of the land for a well site, battery and access road, and certain right of entry orders over the land. The surface lease granted an option to develop an additional surface site. The applicants applied to a chambers judge for a ruling that its exercise of such option effectively enabled it to develop such additional surface site for oil development. The chambers judge held that such option contracts were invalidated by s.12(2) of the Surface Rights Act. ${ }^{136}$ The relevant provisions of s.12(2) are as follows:

(2) Notwithstanding anything contained in a grant, conveyance, lease, license or other instrument, ...and pertaining to the acquisition of an interest in a mineral, an operator does not thereby obtain the right of

(1991), 80 D.L.R. (4th) 766 (Sask. C.A.).

E.A. Leew and M.A. Thackray, "Recent Judicial Developments of Interest to Oil and Gas Lawyers" (1992) 30 Alta L. Rev. 308.

R.S.S. 1978, c. O-2.

(3 June 1991), Calgary 1264 (Alta C.A.) [unreported].

R.S.A. 1980, c. S-27.1. 
entry in respect of the surface of any land unless the grant, conveyance, lease, licence or other instrument provides a specific separate sum in consideration for the right of entry of the surface required for his operations...

The chambers judge further ruled that the power lines which the applicant wished to put on two different sites which it held under the surface rights orders were to be buried so as to interfere as little as possible with the rights of the surface lessor. On the applicant's appeal, the Alberta Court of Appeal overturned the decision, ruling that s.12(2) applies only to surface rights which are mingled with a mineral rights grant, and therefore it was inapplicable to the applicant's option. With respect to the power lines, the Court of Appeal reversed the decision of the chambers judge ruling that it was perfectly reasonable for the applicant to erect overhead power lines along its right of way, absent evidence to the contrary, and that the Surface Rights Act does not limit the applicant in such way.

\section{B. ANTONATION v. MURPHY OIL CO. ${ }^{137}$}

Murphy Oil Company Ltd. was attempting to earn a grant under the Alberta Exploratory Drilling Assistance Program before year end by drilling an exploratory well on Crown land covered by its Crown petroleum and natural oil and gas lease to determine the limits of a pool which had been discovered approximately one mile to the north. Murphy Oil engaged a surveyor to visit the location to survey the proposed wellsite and to stake out possible access routes. The surveyor and Antonation, who held a grazing lease on the land, drew two access options on the Antonation's sketch of the land, Antonation's preference being a route through a treed area, and the other alternative being a route through a cleared area. Several notations were made on the sketch, including one stating "for survey only," and the surveyor and Antonation signed the sketch. The surveyor prepared a plan indicating the proposed access route through the treed area and attached it to applications for a mineral surface lease and a licence of occupation made by a land agent. The land agent was later notified by Alberta Forestry, Lands and Wildlife that the access route through the trees was unacceptable. Antonation then retained a lawyer to represent him in any negotiations with Murphy Oil. Thereafter, Murphy Oil took various steps towards an application to the Surface Rights Board in an effort to obtain a right of entry. Attached to an affidavit of the surveyor in support of Murphy Oil's application was a copy of the original sketch which had been signed by Antonation "for survey purposes only." Murphy Oil contended that Antonation's lawyer's refusal to accept Murphy Oil's contention that Antonation had approved the road site location was a delay tactic. A Public Lands officer then contacted the land agent and advised her that the selected access road location indicated in the application for a licence of occupation was unacceptable. The agent filed a revised application showing the access road through the cleared area, copies of which were never sent to Antonation or his lawyer. The land agent obtained an order for temporary access which was to expire March 1, and Antonation's lawyer withdrew his objection to the well licence. Subsequently, Murphy Oil's supervisor of surface rights contacted the Surface Rights 
Board and informed it that Alberta Public Lands would not approve any access route other than through the cleared area. In fact, Alberta Public Lands had not made any such statement to the supervisor. The supervisor accordingly prepared documents for signature by Antonation and presented them to Antonation's lawyer who objected to the documents because they did not reference the March 1 termination date. Murphy Oil pressed to obtain the order but as it was unable to obtain the consent of the Crown to its application for a right of entry order prior to the end of the year, it could not start drilling before year end and it lost its ability to claim the grant. Antonation sued Murphy Oil and the Board lawyer (but later discontinued that action). Murphy Oil counterclaimed against Antonation and his lawyer, accusing the lawyer of failing to honour an undertaking and of abuse of process intended to prevent Murphy Oil from qualifying for the grant, resulting in $\$ 126,000$ of out of pocket losses.

Hutchinson J. dismissed the counterclaim, ruling that Murphy Oil did not recognize the March 1 termination date and misled the Board's lawyer by stating that another government department would approve only its proposed access route. Further, if there was an agreement with respect to temporary access, Murphy Oil breached the application when it left the termination date out of the application and notice to the Board. Hutchinson J. stated that Murphy Oil was responsible for missing the year end grant deadline, as it could have either compromised by accepting Antonation's preferred access route or promptly moved to apply for a right of entry order without consent. Further, Murphy Oil did not get the required Crown consent by year end or attempt to prove its service of the application on the Crown. One of these factors would have been necessary to have had the right of entry order issued by year end. Finally, there was no evidence of abuse of process by the plaintiff, whose statement of claim concerned the very matter in dispute the access road.

\section{TRANSALTA UTILITIES CORP. v. GREEN $N^{138}$}

The Surface Rights Board set the compensation rate payable by the appellant utility company for transmission lines located on the respondent landowner's land pursuant to the provisions of s. 30 of the Surface Rights Act. ${ }^{139}$ The appellant appealed the Board's decision, contending that its decision was unsupported by evidence and that the Board had considered evidence that it should not have, being evidence presented at other hearings. Prowse J. dismissed the appeal, ruling that the Board had based its ruling on a lengthy consideration of relevant evidence, including its own previous decisions and factual information, such as costs in farming operations, crop fields and farm incomes. In so finding, he referred to the decision of the Alberta Court of Appeal in Caswell v. Alexandra Petroleums Ltd. ${ }^{140}$ which stated that an appeal from the Board "is in the nature of a trial de novo, [but] it is nevertheless an appeal from the findings of the tribunal making the award." 
The Court of Appeal in Caswell also stated that the members of tribunals such as the Surface Rights Board can be assumed to be selected based on their expertise in the field. As they are dealing with similar types of cases on a frequent basis, it must be assumed that the Surface Rights Board has gained experience and accordingly: ${ }^{141}$

When they make detailed findings of fact ... after viewing the area and representations from both sides, and render written reasons as extensive as they did in this case, I think that their findings should not be lightly disturbed. In other words I think it would require cogent evidence to establish where they were wrong and why their awards should be varied or revised upward or downward ... These boards were set up to meet the demand that compensation be fixed on a fair and adequate basis where lands or rights are expropriated for private operations, and considerable weight should be attached to their findings, except where they are clearly demonstrated to be wrong.

With respect to the appellant's second ground of appeal that the Board considered evidence introduced at other hearings, the court stated that, although the Board did consider its previous decisions, there was sufficient evidence specifically introduced at the hearing to justify the Board's decision.

\section{LAND TITLES}

\section{A. CANADA CEMENT LAFARGE LTD. v. MANITOBA ${ }^{142}$}

In this case, the plaintiff sought a determination as to whether the limestone on various lands it acquired over a period of 30 to 40 years was a "mineral" reserved for the Crown. We would refer to the discussion of the Manitoba Court of Queen's Bench decision in last year's paper. The Court of Appeal stated that the only issue on appeal could be whether the trial judge made any errors in his consideration of the evidence presented to him, his interpretation of such evidence and his application of it to the issues at trial, notwithstanding that "...the plaintiff asked this court to retry the case on the same evidence as that which had been presented to the trial judge and to come to a contrary decision." ${ }^{143}$ Despite the warning by the authors of last year's paper that the trial judge might have been mistaken to have relied so much on the definition of "mineral" in each of the Quartz Mining Regulations of $1898^{144}$ and the Dominion Lands Act, ${ }^{145}$ in coming to his decision that limestone could not have been intended to be transferred in Dominion Land Grants which expressly reserved mines and minerals to the Crown, Helper J.A. stated that the trial judge was in fact obligated to examine the use of the term "mines and minerals" in all sources available to him and to interpret such term as set forth in the specific reservations to the Crown. Helper J.A. stated: ${ }^{146}$

\footnotetext{
141. Ibid.

142. [1991] 1 W.W.R. 272 (Man. C.A.).

143. Ibid. at 274.

14. Quartz Mining Act, O.C. 203, March 1898.

145. S.C. 1883 , c. 17.

146. Supra note 142 at 275.
} 
In examining the meaning of the words "mines and minerals" in the reservations, he properly considered the use and meaning of those words in the vernacular of men involved in the industry, commercial men and land owners at the relevant time, the legislation in existence, the composition of limestone, the commercial uses of same and determined that limestone was included in the word "minerals" as set forth in the reservation to the Dominion.

Accordingly, the appeal was dismissed.

\section{B. CANADIAN SUPERIOR OIL LTD. v. JACOBSON ${ }^{147}$}

An owner of freehold mines and mineral rights transferred such rights to Canadian Superior which never registered the transfer. In fact Canadian Superior returned the duplicate certificate of title to the transferor but registered a caveat against the lands in respect of its beneficial interest arising under the unregistered transfer. The defendants became registered owners upon the death of the original transferor and after attempting to get Canadian Superior to remove its caveat, a natural gas lease was entered into between the parties, in respect of which Canadian Superior registered another caveat. After drilling a dry well, Canadian Superior discharged its caveat in respect of the lease. However, it refused several requests by the defendants to discharge its original caveat. Several years later, Canadian Superior drilled a producing gas well on the lands. It then tried to determine to whom royalties should be paid pursuant to an agreement entered into with the original transferor to pay him a percentage of the net proceeds of sale of any natural gas produced from the lands. One of the defendants sued for an order discharging Canadian Superior's caveat. Canadian Superior applied for a declaration of its beneficial interest in the land which the trial judge granted.

The Court of Appeal dealt primarily with the grounds of appeal of estoppel and surrender in dismissing the appeal. With respect to the appellant's argument of estoppel, the court noted that the defendants had not relied to their detriment on the description of the plaintiff as a "Lessee" in their natural gas lease and that the defendants were seeking to "use the doctrine of estoppel as a sword rather than a shield,"148 which according to Denning L.J. in Combe v. Combe ${ }^{149}$ should not be permitted. "That principle does not create new causes of action where none existed before." Further, the court ruled that even if the doctrine of estoppel did apply in this case, which it did not, it would only have applied to the lease between the parties, which had been surrendered by Canadian Superior.

The appellant contended that Canadian Superior could only have entered into the natural gas lease between the parties as a lessee if it had surrendered its beneficial interest in the lands. The court pointed out that such doctrine had only been applied to landlord and tenant situations, with one exception, and ruled that due to the close relationship between the doctrines of estoppel and surrender, as there were no grounds for estoppel here, there could be no grounds for finding that Canadian Superior had surrendered its 
beneficial interest in the lands by operation of law. Accordingly, the appeal was dismissed.

\section{CANCO OIL AND GAS LTD. v. SASKATCHEWAN 150}

The applicant was an assignee of "a gross royalty of $3 \%$ of all petroleum, natural gas and related hydrocarbons, (except coal) ... which are ... produced, saved and sold" from certain lands, which was originally granted by the owner of an undivided four-fifths interest in all minerals in the lands. The royalty agreement further provided that:

(a) the grant ... herein made relates to and constitutes an interest in the land with express right on the part of the Grantee to register and maintain caveats, against the freehold titles without adverse claim ever being made by the Grantor or any person claiming by, through or under the Grantor;

(b) the covenants herein contained shall run with the land ...

Under the provisions of the Oil and Gas Conservation Stabilization and Development Act, ${ }^{151}$ the Crown became the registered owner of an undivided three-fifths interest in the minerals in the lands. It served a notice to vacate the caveats registered by the applicant and a successor in title to the applicant, asserting that the original royalty agreement did not create an interest in land. The applicant countered with an application for an order maintaining the registration of the caveats.

In finding in favour of the applicant, the court walked through an extensive review of the various decisions dealing with grants of royalties vis-a-vis the royalty's nature as a contractual right as opposed to an interest in land, including the decisions in St. Lawrence Petroleum Ltd. v. Bailey Selburn Oil \& Gas Ltd. ${ }^{152}$ Emerald Resources Ltd. v. Sterling Oil Properties Management Ltd., ${ }^{153}$ Bensette v. Reece, ${ }^{154}$ Vanguard Petroleums Lid. v. Vermont Oil \& Gas Resources Limited, ${ }^{155}$ Berkheiser v. Berkheiser, ${ }^{156}$ Dawson v. Bell, ${ }^{157}$ Keyes v. Saskatchewan Minerals ${ }^{158}$ and Frobisher Ltd. v. Canadian Pipelines \& Petroleums Ltd. ${ }^{159}$ The court summarized those decisions by suggesting that they stood for two elements which were essential for a royalty to be an interest in land: ${ }^{160}$

a corresponding right to enter upon, explore for and extract petroleum substances", [and] ... a grant, or reservation, of an in situ interest in mines and minerals, albeit expressed as a royalty interest, that would

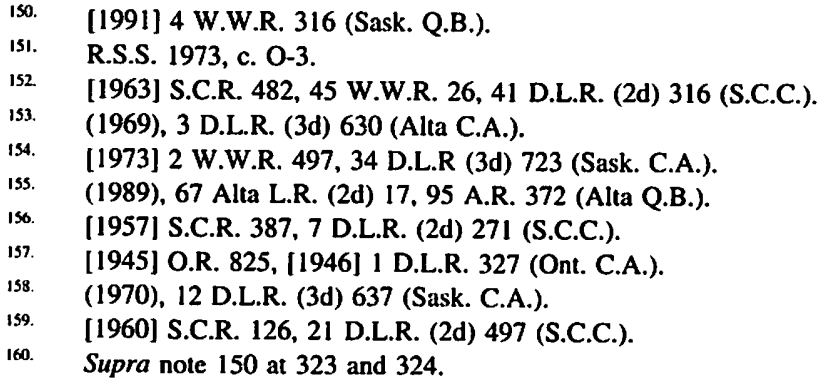


necessarily detract from the title of the fee simple owner of the mines and minerals, and be tantamount to a grant of an undivided interest in the mines and minerals, resulting in co-ownership.

The court then cited St. Lawrence, Berkheiser, Keyes and Montreal Trust Co. v. Gulf Securities Corp. ${ }^{161}$ and stated that the Supreme Court of Canada has indicated that a dominant factor to be considered in determining whether royalties constitute an interest in land is the wording of the agreement creating the royalty. In this case, the grantor of the royalty, as the fee simple owner of an undivided interest in the mines and minerals, obviously possessed an interest in land and was therefore capable of granting an interest in land. It clearly intended to create and convey an interest in land by virtue of the express wording of the royalty agreement. Accordingly, the court concluded that an interest in land was created and therefore that the caveats shall remain registered. The Crown appealed.

\section{CANCO OIL AND GAS LTD. v. SASKATCHEWAN ${ }^{162}$}

The Saskatchewan Court of Appeal questioned the propriety of the lower court deciding the matter before it summarily in light of the judgments of the Court of Appeal in Amoco Canada Resources Ltd. v. Potash Corporation of Saskatchewan Inc. ${ }^{163}$ and Block et al v. Sceptre Resources $L t d .^{164}$ In this case, both parties took the position that a summary disposition of the matter had been appropriate given the fact that there was an agreed statement of facts, there was no further evidence to be given at trial and the resolution of the question would be resolution of all disputes between the parties respecting one group of caveats. However, the Court of Appeal felt that whatever decision it reached, such decision would effect the rights and liabilities of the parties who were original parties to the Royalty Agreement, dated May 10, 1963, or their assignees, and accordingly, the court ordered that all of such parties receive notice of the next step to be taken in this matter.

With respect to the next step to be taken, Sherstobitoff J.A. ordered that Canco was to make an election and advise the registrar of its election within one week of the date of this judgment between two alternate methods of proceeding:

(1) Canco could give notice of the original hearing, as well as a copy of the Court of Appeal judgment and the fact that it was filed, to the original parties to the agreement and all of their respective assigns or successors. All of such parties would then be entitled to appear at the hearing and make representations. If at such time all parties present agreed to a summary disposition of the matter, then the court would proceed in that fashion. In the interim, there would be an order maintaining the caveat until the determination of the issue or otherwise.

(2) The Province of Saskatchewan could commence an action to determine the question in issue. It would be required to join as parties all of the original 
parties to the agreement and all of their respective successors and assigns. If this alternative were chosen, such action was to be commenced within $\mathbf{3 0}$ days of this Court of Appeal judgment. At the trial, the trial judge would not be allowed to consider the judgment in the court below, as that judgment was determined in a summary fashion. Again, there would be an order maintaining the caveat until the action is determined, or until otherwise ordered.

\title{
E. AMOCO CANADA RESOURCES LTD. v. POTASH CORPORATION OF SASKATCHEWAN INC. ${ }^{165}$
}

The chambers judge's decision was reported in last year's paper. ${ }^{166}$ The Saskatchewan Court of Appeal allowed the appeal by Amoco of the decision dismissing its application to continue its caveats. Cameron J.A. stated that such decision was effectively a final determination of substantive issues between the parties. He stated: ${ }^{167}$

\begin{abstract}
The chambers judge was not bound, as though sitting as a trial judge, to have made a final determination of the substantive issues based on the evidence before him. The proceedings were summary in nature, and it was open to him to have directed a trial of the issues, continuing the caveat in the meantime, or to have continued the caveat on the condition that a declaratory action be commenced. Indeed it was not only open, but virtually incumbent upon him, to have done so given the character, complexity and general importance of the issues, coupled with the paucity of evidence before him.
\end{abstract}

\section{F. CANADA (DIRECTOR OF SOLDIER SETTLEMENT) v. SNIDER ESTATE ${ }^{168}$}

For background on the earlier decisions in this case, we would refer to the discussion of the Alberta Court of Appeal decision in the 1989 paper. ${ }^{169}$ The Soldier Settlement $A c t^{170}$ of 1919 provided that the Soldier Settlement Board could acquire land and resell it to veterans of the First World War. In September, 1919 the title to certain lands was transferred to the federal Crown "as represented by the Soldier Settlement Board" excepting only coal. In 1920, the Board registered the lands under the Land Titles Act of Alberta. ${ }^{171}$ The federal Soldier Settlement Act $^{172}$ stated that all sales of land were deemed to reserve all mines and minerals. The Board sold the lands, excepting only coal, to the predecessor of the respondents, taking a mortgage back. The transfer and mortgage were registered. The transferee subsequently sold the lands to the respondents for value and titles were issued in the respondents' names for the mines and minerals, except coal. The Natural Resources Transfer Agreement of 1930 (hereinafter the "Transfer

(1991), 93 Sask. R. 300 (Sask. C.A.).

E.A. Leew \& M.A. Thackray, "Recent Judicial Developments of Interest to Oil and Gas Lawyers" (1992) 30 Alta L. Rev. 308 at 373.

Supra note 165 at 305.

[1991] 5 W.W.R. 289 (S.C.C.).

R.P. Desbarats, "Recent Judicial Decisions of Interest to Oil and Gas Lawyers" (1990) 28 Alta L. Rev. 254 at 278.

S.C. 1919, c. 71 .

R.S.A. 1922, c.133 (now R.S.A. 1980, c. L-5).

S.C. 1917 , c. 21 , S.C. 1919 , c. 71. 
Agreement") dealt generally with the transfer of the federal Crown's interest in all mines and minerals to the Province of Alberta, but s. 13 of the Agreement expressly excepted from such transfer "all interests in Crown lands in the province upon the security of which any advance has been made under the provisions of the Soldier Settlement Act." In 1979, the appellant Director of Soldier Settlement applied for an order cancelling the respondents' titles to the mines and minerals and issuing a new title in the name of the appellant (excepting coal). The order was granted. The Attorney General, who had intervened at trial, appealed to the Court of Appeal, which reversed the decision of the trial judge. The Director appealed to the Supreme Court of Canada.

Stevenson J., for the majority, pointed out that the Alberta Court of Appeal reversed the trial judge's decision not based on the issue of whether the mines and minerals were transferred under the Transfer Agreement to Alberta but rather on the basis that, as the federal Crown had chosen to bring itself under the Alberta Land Titles Act regime by registering its original transfer, it was subject to the rules of indefeasibility of title in the Torrens system. Therefore, the respondents were entitled to be registered as the owners of the mines and minerals. Justice Stevenson then considered three issues:

\section{Does Section 57 of the Soldier Settlement Act apply?}

The Supreme Court supported the findings of the Alberta Court of Appeal that 5.57 of the Soldier Settlement Act did reserve the mines and minerals to the federal Crown after the Crown obtained the same in 1919 by way of transfer from the registered owner at that time.

\section{Constitutional Issues}

Stevenson J. upheld the position of the respondents that the mines and minerals had been transferred to the Province of Alberta pursuant to the Transfer Agreement and therefore, as the provincial Crown was clearly bound by the Land Titles Act, the Torrens system would not allow the respondents' titles to be challenged. Accordingly, it was not necessary to address the issue of whether the federal crown was, in this case, bound by the Land Titles Act of Alberta which the Alberta Court of Appeal had held it was.

\section{The Transfer Agreement}

The Supreme Court unequivocally stated that unless the federal Crown's claim to the mines and minerals at issue falls within one of the exceptions enumerated in the Transfer Agreement, the rights would have transferred to the provincial Crown. Further, as the Transfer Agreement is a constitutional document, its exceptions were to be interpreted restrictively. 
The Supreme Court agreed with the trial judge in rejecting the application of the exception contained in s. 13 of the Soldier Settlement Act to the case at bar for two reasons. Mr. Justice Stevenson stated: ${ }^{173}$

Firstly, as of the date of the agreement neither the surface nor the mines and minerals in question were Crown lands subject to security. Secondly, there was no "advance", within the meaning of the Soldier Settlement Act.

In reaching its conclusion on the second point, the court analyzed ss. 16 to 19 and s.25 of the Soldier Settlement Act and commented that: ${ }^{174}$

... one can see that the Act distinguishes quite clearly between advances made under it and unpaid amounts owing by settlers to the board on, for example, the sale to settlers of the settlers' land ... [a]ccordingly, one cannot conclude that there was an advance within the meaning of para. 13 of the agreement.

In deciding that the exception set out in paragraph 18(a) of the Transfer Agreement (which excepted "any lands for which Crown grants have been made and registered under the Land Titles Act of the Province and of which His Majesty the King in the right of His Dominion of Canada is, or is entitled to become the registered owner at the date upon which the agreement comes into force") did not apply to the mines and minerals at issue in this case, Stevenson J. stated: ${ }^{175}$

The office of para. 18(a) is, in my view, to protect surface grants which the Crown has made to itself and were in the form of titles in the Crown, or in the process of registration. ...It cannot have been meant to extend to the extensive mineral reservations under the surface of granted lands in respect of which the Crown would be, at the time of the agreement, "entitled to become the registered owner."

Accordingly, the Supreme Court of Canada dismissed the appeal and declared the respondents entitled to the mines and minerals, excepting coal.

\section{G. ALTA. (MINISTER OF FORESTRY, LANDS \& WILDLIFE) v. $M C C U L L O C H^{176}$}

The Crown sold two parcels of land included in one title. One parcel was residential and the other covered a millsite. The sale was made to a corporation. The terms of the agreement bound the purchaser to use the land only for specified purposes and granted an option to the Crown to repurchase the land at a predetermined price. The corporate purchaser went into receivership, and when the millsite parcel was sold to the defendant, it was subject to the original caveat. However, when the residential parcel was later sold to a third party and the caveat was to be discharged from that parcel, through a Land Titles Office error the caveat was also discharged from the millsite parcel. The defendant 
discovered that the caveat had been mistakenly discharged and informed a Crown employee who confirmed that such discharge must have been a mistake. Then, within a few days, the defendant transferred the title to a corporation of which he was a director, shareholder and officer, and granted his original lender new security over the new title. The Crown filed a new Caveat against the new title for the property and refused to reacquire the parcel when offered by the defendant under any terms other than those under the original agreement. The Crown then made an application for a declaration that the defendant's actions constituted fraud under the Land Titles Act $^{177}$ and that the corporation's and its mortgagee's interests were subject to the interest of the Crown which had been protected by its original caveat.

The relevant section of the Land Titles Act is s. 195 which states:

Except in the case of fraud, no person contracting or dealing with or taking or proposing to take a transfer, mortgage, encumbrance or lease from the owner of any land in whose name a certificate of title has been granted shall be bound or concerned to inquire into or ascertain the circumstances in or the consideration for which the owner or any previous owner of the land is or was registered or to see to the application of the purchase money or any part thereof, nor is he affected by notice direct, implied or constructive, of any trust or unregistered interest in the land, any rule of law or equity to the contrary notwithstanding, and the knowledge that any trust or unregistered interest is in existence or shall not of itself be imprinted as fraud. [emphasis added]

Sinclair J. confirmed that, as enunciated by Supreme Court of Canada in Union Bank of Canada v. Boulter Waugh Ltd., ${ }^{178}$ there must be more than knowledge to constitute fraud under the Act: ${ }^{179}$

Knowledge, of course, could not of itself constitute fraud. Fraud must always have consisted in the doing of something which that knowledge made it unjust or inequitable to do.

Sinclair J. then reviewed the circumstances leading to the transfer of the title to the defendant's corporation and determined that such actions of the defendant did in fact amount to fraud under the Land Titles Act: ${ }^{180}$

It seems like more than a coincidence that the transfer, including the new arrangements with the Treasury Branch, was carried out within a few days after Mr. McCulloch learned that the caveat had been discharged. I believe the transfer to the limited company was also made for the purpose of defeating the department's interests and of relieving Mr. McCulloch from his obligations to the department. 


\section{H. ALTA. (MINISTER OF FORESTRY, LANDS \& WILDLIFE) v. MCCULLOCH ${ }^{181}$}

The appeal was dismissed by the Court of Appeal. The court held that as McCulloch controlled the transferee numbered company, then the intent of McCulloch as transferor was relevant, and such acts were fraud "in the narrow and a strict sense." Both McCulloch as transferor and the numbered company as transferee shared the fraudulent intent, which was more then mere knowledge on the part of the transferee. Further, the court ruled that given the pleadings and the lack of an opening statement by the appellants at trial, it was doubtful that the appellants' position that the contract had been discharged or frustrated was even open to argue. However, even if such grounds were open to argue, the Court of Appeal felt that there was nothing done in this case which would have constituted frustration or discharge of the contract.

\section{LAC LA RONGE INDIAN BAND v. BECKMAN ${ }^{182}$}

The plaintiff Indian Band commenced actions in Federal court against both the federal and the provincial Crown and in the Saskatchewan Court of Queen's Bench against the Province of Saskatchewan. It sought declarations that the federal and provincial governments were required to fulfil the terms of Treaty 6 . It then filed caveats against certain patented and unpatented lands in the Candle Lake resort area in the Province of Saskatchewan. The basis of the claims set out in the caveats was that, inter alia, at the time that the federal government transferred the title to Crown lands in Saskatchewan to the Province under the terms of the 1930 Crown Lands Transfer Agreement, an Indian reserve existed on the lands in the Candle Lake area and therefore all such lands were not conveyed to the Province under the terms of the Transfer Agreement. The first caveat was filed against unpatented crown lands and the second caveat was filed against patented lands in the name of freehold owners. Several of the freehold title owners served notices to lapse the caveat filed against their properties and the Band responded with an application for an order continuing the caveats indefinitely against such lands. The Province also applied for an order requiring the Band to substantiate its claim under the terms of the caveat against the unpatented lands. The trial judge determined that there were no facts at issue and that the cases dealing with the jurisdiction of the court to determine the merits of a disputed claim for an interest in land mandated that the court only has the power to determine the right to file a caveat and not to decide the merits of a disputed claim to an interest in land unless "the parties agree that the matter be determined by affidavit, or where the facts are simple and not in dispute, or where the material clearly discloses no caveatable claim, so that the matter may be disposed of similarly...." ${ }^{183} \mathrm{He}$ decided that the appellant Band did not possess an interest in the land in question. Accordingly, he ordered that its caveat be removed from the lands in question.

183. Ibid. at 216 
The Saskatchewan Court of Appeal held that the trial judge did not have the jurisdiction to finally determine the question of the appellant Band's claim to an interest in the Candle Lake lands. It did so on the basis that the Band had not consented to a summary disposition of the issue and that it could not be said that the material before the court evidenced no claim. Further, the facts and issues before the court were not uncomplicated or not being disputed. On this last point the court stated that: ${ }^{184}$

...in any event, it was not for the judge but for the Band to decide whether there was further evidence which it might wish to tender at the trial. The Band did not concede the non-availability of further evidence, nor was it under any obligation to tender all available evidence on an interlocutory proceeding such as was before the court. It was, if permitted to proceed with the actions, entitled to discovery from the opposing parties which might disclose further evidence. In summary, this was a case manifestly unsuitable for summary disposition.

With respect to the issue of whether or not the caveats against the lands should be vacated, the Court of Appeal decided that because the Band was arguing that it was not subject to the Land Titles Act ${ }^{185}$ as its claim preceded the transfer of the lands from the federal Crown to the provincial Crown, it could not then rely upon the provisions of the Land Titles Act to register caveats. Accordingly, for this reason, the caveats could not remain registered. Further, in the event that the Band was successful against the federal government with respect to its claim for support under Treaty 6, its claim could only succeed against the federal Crown and not against the private owners of the patented lands. For that reason, the claim of the Band could not be the basis of a caveatable interest against the private owners. Finally, the court pointed out that the proper recourse for the Band would be the filing of lis pendens under the Queen's Bench Act ${ }^{186}$ rather than caveats filed under the Land Titles Act.

\section{J. SHAGANAPPI VILLAGE SHOPPING CENTRE LTD. v. PETRO-CANADA INC. ${ }^{187}$}

The appellant owned a shopping centre. Its predecessor in title had granted to the respondent's predecessor an easement to allow the customers of the respondent, which was a service station, to access the service station. The respondent's predecessor had registered a caveat against the property and had maintained such registration for a period of 17 years. When the immediate predecessor in title to the appellant obtained the property, the sale agreement pursuant to which it obtained such property excluded the caveat from the schedule of permitted encumbrances. Thereafter, such predecessor obtained an ex parte order on the basis of a false statement removing the caveat from the title. Subsequently, the appellant purchased the property with no evidence of the caveat registered thereon. A chambers judge granted an interim injunction preventing the appellant from erecting a chain link fence between the properties, thereby cutting off the respondent's customers' previous access to the respondent's service station.

R.S.S. 1978, c. L-5.

R.S.S. 1978, c.Q-1

(1990), 14 R.P.R. (2d) 127 (Alta C.A.). 
On appeal, the court stated that the sole issue to be decided was whether the easement was enforceable by the respondent against the appellant notwithstanding that, when the appellant took title to the lands, the caveat was no longer registered against the title. The court reviewed the provisions of s.65(1)(g) of the Land Titles Act which provide that:

The land mentioned in any Certificate of Title ... is, by implication and without any special mention therein, subject to ... any right of way or other easement granted or acquired under any Act or law enforced in Alberta.

After reviewing the authorities, the Court of Appeal ruled that private easements created by virtue of contract, as opposed to easements arising by statutory operation of law, are not covered by the provisions of s. $65(1)(\mathrm{g})$. Accordingly, the appeal was allowed and the injunction was ordered vacated.

\section{K. LIEDING v. ONTARIO ${ }^{188}$}

The predecessor of the appellant was granted certain crown mining lands by way of letters patent which reserved to the Crown "all trees standing or being on said land." The grant was also expressly subject to s. 102 the Mining Act, ${ }^{189}$ which provided that ". . all trees or timber of whatever kind growing or being thereon shall be reserved to the Crown ..." The trial judge dismissed the appellant's action for a declaration it was the owner of all trees on the surface of the lands in question that came into existence after the date of original grant.

Although the Ontario Court of Appeal stated that the trial judge had come to the correct conclusion, it felt that he had done so on the wrong basis. The court pointed to the language in s. 102(1) of the Mining Act and also relied upon s. 4 of the Interpretation $A c t,{ }^{190}$ which provides that:

The law shall be considered as always speaking, and whenever any matter or thing is expressed in the present tense, the same is to be applied to the circumstances as they arise, so that effect may be given to each act and every act thereof according to its true intent and meaning.

The Court of Appeal then concluded that, notwithstanding the normal present tense connotation of the word "growing," when such word appears in a document that incorporates s. 102(1) of the Mining Act, together with the rule of interpretation set out in s. 4 of the Interpretation Act, that reference must be to trees growing at any point in time. In addition, the court reviewed extensive case law and other authorities that pointed out, inter alia, that when there are two possible interpretations of a grant, the interpretation that is the most favourable to the Crown shall be the one that is followed. Based on these reasons, the appeal was dismissed. 


\section{DUNCAN v. WEST KOOTENAY POWER AND LIGHT COMPANY'191}

In 1961, the plaintiffs granted easements to the defendant company which allowed the defendant to install and maintain power lines and other apparatus involved in power lines and to access the easements to maintain and repair such power lines, and they also reserved to the plaintiffs the right to cultivate the land. In 1985, the defendant decided to drastically repair and replace its line along the plaintiffs' property, including replacement of the line itself, which would require that large equipment and vehicles have access to its easement for the purpose of supplying all of the necessary materials to the construction project. Owing to the weight and size of these vehicles, the defendant company decided that it would be necessary to construct a new road across its easement on the plaintiffs' property. When it advised the plaintiffs of its desire to negotiate wider easements for these purposes, the plaintiffs refused to allow the defendant access and applied for an interlocutory injunction preventing the defendant from constructing a permanent road across their properties and the lands covered by the easement. The judge who heard that application dismissed the application, as he felt that since the defendant had powers of expropriation, to grant such an injunction would be fruitless. However, he ordered the defendant to give proper notice to the plaintiffs of the proposed work. After extended negotiations, an agreement was reached between the parties by way of telefaxes whereby, inter alia, the parties agreed that the defendant would have the right to access the easement by existing roads on the easement and, to the extent that additional roads were necessary, it would use existing roads that were not on the easement rather than building new ones on the easement lands. In addition, the defendant agreed to use its best efforts to minimize the amount of road work required. In performing its work on the easement lands, the defendant found it necessary to level the existing roads and to upgrade them to allow access for their heavy equipment. After such work was completed, the plaintiffs brought an action against the defendants claiming that the nature of the roads had been altered and that the construction of such new roads had drastically disturbed the surface of the easement lands rendering them unable to be cultivated. The trial judge awarded the plaintiffs damages for trespass and breach of the easement agreements and, in addition, awarded the plaintiffs exemplary damages as he found the conduct of the defendant to be "high-handed" and reprehensible.

The trial decision was overturned on appeal, MacDonald J.A. held that, although the terms of the original easement did not allow the defendant access to easement lands to build roadways to complete the type of construction that it undertook in this case, the subsequent agreement between the parties gave the defendant additional rights with respect to existing roads both on the easement lands and off the easements.

With respect to the lower courts award of exemplary damages against the defendant, the Court of Appeal found that there was no evidence of "harsh, vindictive, reprehensive and malicious" conduct and, therefore, the decisive factor for an award of exemplary damages was missing. Accordingly, it allowed the appeal and overturned the award of exemplary damages. 


\section{LEAVE TO APPEAL TO SUPREME COURT OF CANADA}

\section{A. AIR CANADA v. $M$ \& L TRAVEL LTD. ${ }^{192}$}

Leave to appeal to the Supreme Court of Canada was granted on November 14, 1991.

B. BAVARIAN LION CO. v. ALBERTA DIRECTOR OF POLLUTION CONTROL ${ }^{193}$

Leave to appeal to the Supreme Court of Canada was denied on April 18, 1991.

C. GUARANTY TRUST CO. v. HETHERINGTON ${ }^{194}$

Leave to appeal for the Supreme Court of Canada was denied on December 21, 1989.

D. MOHAWK OIL CO. v. CANADA ${ }^{195}$

Application for leave to appeal to the Supreme Court of Canada was filed on March 26, 1992.

E. PANAMERICANA DE BIENES Y SERVICIOS v. NORTHERN BADGER OIL \& GAS $L T D .^{196}$

Leave to appeal to the Supreme Court of Canada was denied on January 16, 1992.

F. R. v. FOOTHILLS PIPE LINES (SOUTH YUKON) LTD. ${ }^{197}$

Leave to appeal to the Supreme Court of Canada was denied on April 25, 1991.

G. FOREST OIL CORP. v. HUSKY OIL OPERATIONS LTD. ${ }^{198}$

Leave to appeal to the Supreme Court of Canada was denied on October 3, 1991.

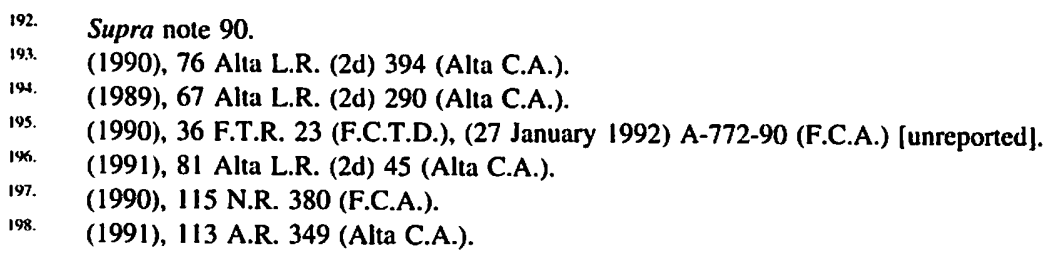

